\title{
日本の私鉄における貨物輸送の性格*
}

一運輸密度と貨物品目構成を中心として—

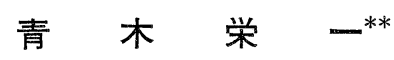

日本の私鉄は抢打む対局地鉄道としての性格をもち, 沿線地域の産業活動が鉄道の貨物輸送に直接反映す る可能性が高い.このことから私鉄の貨物輸送の実態を全国的, 総括的に把握するため, 貨物運輸密度 (1 日 1 キロ当り貨物平均通過トン数）および輸送貨物の品目構成から明らかにしようと試みた.

考察の結果，日本の私鉄の大部分は貨物品目構成の上で，農産品または林産品，あるいはその両者の発送， および肥料の到着が大きい比率を占める I 型(第 1 次産業基盤の私鉄), 鉱産関係品の発着, あるいはセメン トの発送が大きい比率を占める亚型(第 2 次産業基盤の私鉄)，および I ・ III型の中間型である II 型の 3 者に 分類することができた。I・II・III各型に属する線区数は調查私鉄 113 線区 $(1955 \sim 56$ 年現在，総数の $83 \%$ に相当) 中，それぞれ $43(38 \%) ， 17(15 \%) ， 38$ (34\%) であった。 また一般に貨物運輸密度の高い線区では 第 2 次産業生産物およびその関連貨物の比率が高く, III型に属し, 第 1 次産業生産物およびその関連貨物の 比率が高い線区では貨物運輸密度が低い。

序 言

日本の私鉄 ${ }^{1)}$ は「地方鉄道」という法制上の呼称 が示すように，ある局限された範囲の地域にサービ スする機能をもつ鉄道，すなわち局地鉄道の範疇に 含まれる鉄道である．私鉄は一般に路線営業キロが 短かく，形態的には国鉄線より分岐する袋小路的な 線区である場合が多く，それ自体のみでは交通流の 上で完結した鉄道網を形成し得ない、私鉄の中には 大都市地域にあって，長大な路線網とその中で交通 流の大部分が完結する鉄道網をもつ場合もあるが， 本論文では，比較的短小な路線とそれ自体のみでは 交通流の上で完結しえないような鉄道網をもつ私鉄 を主な研究対象とし，その貨物輸送の特質を運輸密 度と輸送貨物品目構成の上から明らかにしたい。

\section{I 運輸密度の意義}

「運輸密度」(traffic density)とは交通線上におけ る単位時間，単位距離あたりの平均通過交通量をい 万。 日本国有鉄道では年間の通過交通量を 1 日 1 キ ロあたりに換算したものを用い，イギリス国鉄では 1 週 1 マイルあたりの数值をもって表わしている. したがって，運輸密度によって路線の長短に関係な く，異なる路線上の交通量の大小を比較することが できる。

交通地理学の分野において, 始めて運輸密度の 概念を導入した研究を発表したのはウォーレス (William H. Wallace) であり ${ }^{2)}$, 鉄道の運輸密度が 沿線地域の産業活動や路線網の形態と密接に関係し ていることを世界の鉄道の実際例を通じて明らかに

* 本論文は筆者の東京教育大学大学院理学研究科における博士論文の一部であり，1965年 4 月，日本地理学 会大会に扔いて発表した内容を含んでいる.

水都留文科大学

1）私鉄とは「私設鉄道」の省略形で，本来は明治期の私設鉄道条約およびその後身たる私設鉄道法によっ て監督される鉄道をいう。しかしこのような法制上の私設鉄道がすでに存在しない今日では，私鉄とは国 有鉄道以外の一般営業を行なう鉄道の俗称で，法制上の「地方鉄道」と「軌道」を併せたものの総称とし て使われている.

2）交通地理学の系譜におけるウォーレスの位置づけについては，青木栄一（1967）：鉄道交通地理学の系譜 と方法論に関する考察. 都留文科大学研究紀要， 4, 13 21. および，青木栄一（1968）：交通地理学の系 譜. 交通地理学(有末・柾・青木共編, 大明堂刊) 16 28 参照. 
しだ?.

しかしながら，ウォーレスが行なったような国家 を単位とする巨視的な研究を直ちに小地域の微視的 研究に適用することは困難であり，幹線鉄道と局地 鉄道とでは通過交通量の性格が異なっている。すな わち，前者にあっては沿線地域に発着しないまった く通りすぎるだけの交通流を多く含むのに対して， 後者では通過交通量のほとんど全部が沿線地域に発 着する交通流によって占められるししたがって幹線 鉄道における運輸密度は必ずしも沿線地域の産業活 動その他の地域の活動状態を反映しているとは限ら ないが，局地鉄道の運輸密度はその沿線地域の産業
活動などによって大きく影響される.

\section{II 私鉄の貨物運輸密度己輸送貨物品目構成}

一般に貨物運輸密度が高い私鉄名をみると，その 存在する地域から，その私鉄が特定の産業に関係す る貨物の輸送を主体としていることが予想される. そこで, 各私鉄の貨物運輸密度は特定の貨物品目の 輸送と何らかの関連があると考えられたので，私鉄 ごとに輸送貨物の品目構成を調べ，両者の関係をよ り明確に把握しようと試みた。

私鉄の貨物は同一私鉄線区内のみを輸送されるこ とは少なく，私鉄線区内に発着する貨物の大部分は 第 1 表 主 要 貨 物 品 目 明 細 表

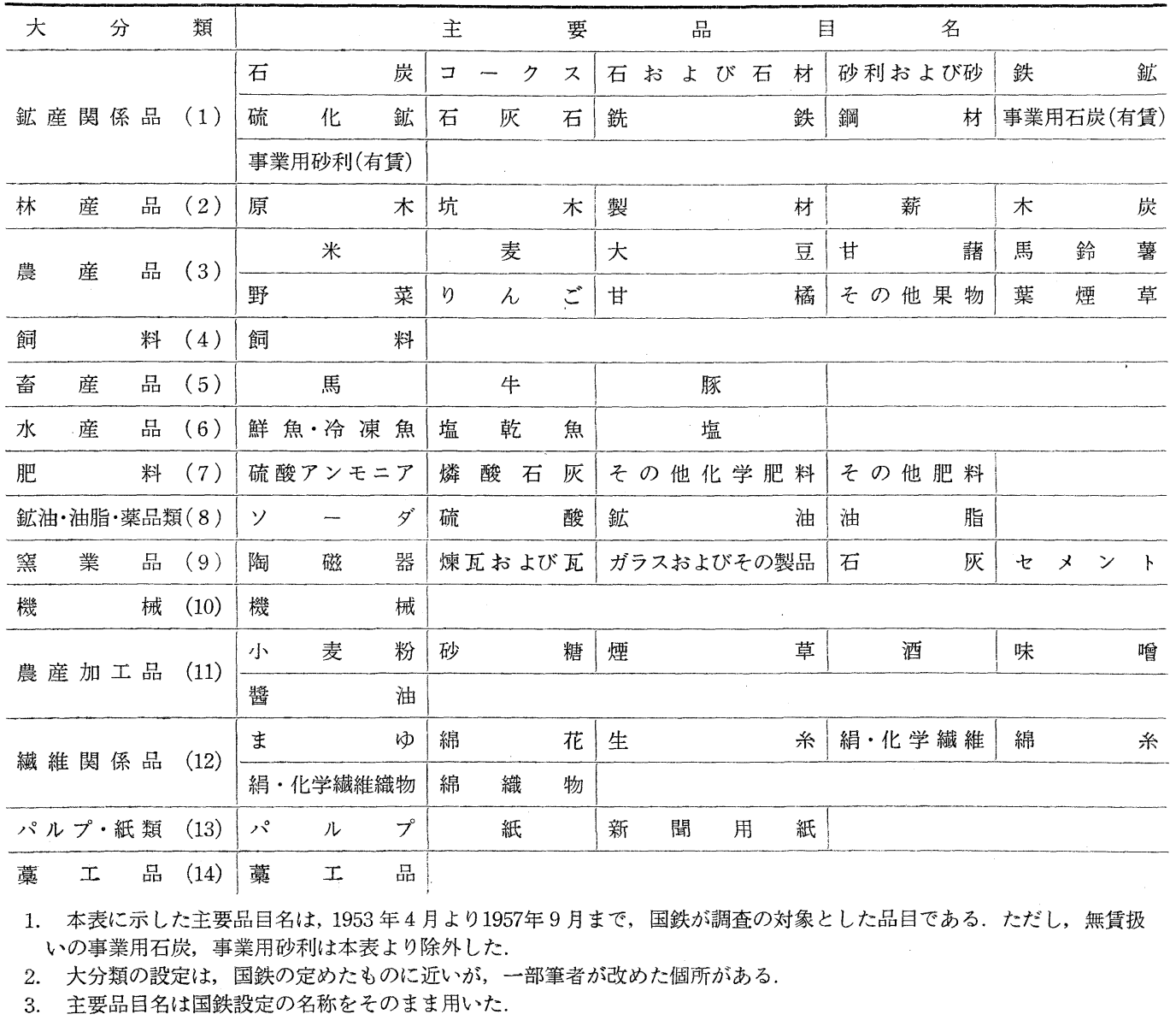

3) Wallace, W.H. (1958) : Railroad Traffic Densities and Patterns, A. A. A. G., 48, 4, 352 374. 
国鉄線内に到着，あるいは国鉄線内から発送されて いる.また貨物輸送を行なう私鉄の大部分は国鉄と 連帯運輸を行なっている。したがって，国鉄との間 の連帯貨物トン数についての品目別構成をもって, その私鉄全体の貨物品目別構成とみなしても差支え なく，かつ統一された基準で資料を揃えることがで きる.

このための資料としては，1956年度のものを使用 したが，北海道の私鉄はこの年度の統計が不備のた め1955年度の資料を使用した4).

1955年度および1956年度において，国鉄が「主要 貨物」として品目別に統計調査の対象としたものは 全部で70品目であり, この他に事業用品 4 品目 ${ }^{5)}$ が ある、これらを第 1 表のように, 鉱産関係品, 林産 品, 農産品, 飼料, 畜産品, 水産品, 肥料, 鉱油 油脂 - 薬品類, 宰業品, 機械, 農産加工品, 繊維関 係品, パルプ・紙類, 踩工品の計 14 種の大分類品目 に統合し，連帯貨物総トン数に対する大分類品目の トン数の百分率を算出した. ただし, 事業用品 4 品 目中，有賃扱いの事業用石炭と事業用砂利は鉱産関 係品に含んだが，無賃扱いの事業用石炭と事業用砂 利は鉄道統計年報の発着トン数総計に含まれていな いので削除した。

これによる各私鉄の貨物品目構成を第 2 表の左側 に示した。

これでみると，鉱産関係品の発送・到着，セメン トが主となった場合の亚業品の発送および肥料の発 送の多い私鉄は一般に貨物運輸密度が高いのに対し， 林産品, 農産品の発送の大きい私鉄は一般に肥料の 到着が多く，貨物運輸密度は中位ないし低位に止ま っている，すなわち，鉱産関係品，セメントの搬出 を役割とする私鉄，あるいは鉱産関係品を原料とし
て搬入する役割の重化学工業地帯の私鉄は一般に貨 物運輸密度が高く, 農・林業を主要な産業とする地 域の私鉄は貨物運輸密度が低くなる傾向にあること が指摘できる.

この傾向を更に明確にするため, 貨物品目の大分 類を更に統合して，次のような三つの品目群を設定 した。

\section{第 1 次産業的品目群}

発送：林産品, 農産品, 飼料, 畜産品, 水産品 到着 : 肥料

\section{第 2 次産業的品目群}

発送：鉱産関係品, 肥料, 鉱油・油脂・薬品類, 窯業品, 機械, 農産加工品, 繊維関係品, パルプ・紙類.

到着 : 鉱産関係品, 鉱油・油脂・薬品類.

\section{その他の品目群}

発送: 獣工品, その他 ${ }^{6)}$

到着 : 林産品, 農産品, 飼料, 畜産品, 水産品, 葖業品, 機械, 農産加工品, 繊維関係品, パルプ・紙類, 营工品, その他 ${ }^{6)}$

すなわち，「第 1 次産業的品目群」とは，私鉄の 貨物が沿線地域の第 1 次産業との関連のあるもので あった場合に，品目構成の上で卓越すると考えられ る品目の集団であり,「第 2 次産業的品目群」とは, 同様に第 2 次産業と関連する場合に卓越する品目の 集団である.「その他の品目群」は鉱産関係品と肥 料, 鉱油・油脂・薬品類を除いた到着品目を主とし たものであるが，それが沿線地域のいかなる性格を 表わすものであるかについては，にわかに断定でき ない。

以上によって, この 3 品目群の構成百分比を算出 すれば，「第 1 次産業的品目群」や「第 2 次産業的

4）日本国有鉄道：主要貨物駅別トン数年報. 昭和 31 年度および同昭和 30 年度.この資料に示された数值は 車扱貨物のみであり，輸送貨物トン数の大部分を占める.

5）国鉄の業務用として輸送する品目. 有賃扱いと無賃扱いとがあり，鉄道統計年報では有賃扱いのものの みを統計に算入している，原則的には私鉄との間の連帯貨物には無賃扱いは存在しない.

6）第 2 表に示した「主要貨物」以外の車扱貨物一切を示す. 
第 2 表 私 鉄 の 貨

\begin{tabular}{|c|c|c|c|c|c|c|c|c|c|c|c|c|c|}
\hline & 私 鉄 名 & $\begin{array}{l}\text { 貨物運 } \\
\text { 輸密度 }\end{array}$ & 発着 & 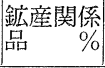 & 林産品\% & 農産品\% & 飼料\% & 畜産品\% & 水産品\% & 肥料\% & $\begin{array}{l}\text { 鉱油・油脂・ } \\
\text { 楽品類 } \%\end{array}$ & 窯業品 \% & 機械\% \\
\hline 1 & $\begin{array}{l}\text { 釧路 } \\
\text { 臨港鉄道 }\end{array}$ & $\begin{array}{r}\text { トン } \\
1,267\end{array}$ & $\begin{array}{l}\text { 登 } \\
\text { 着 }\end{array}$ & $\begin{array}{r}26.6 \\
6.2\end{array}$ & $\begin{array}{r}0.5 \\
22.7\end{array}$ & $\begin{array}{l}2.0 \\
0.7\end{array}$ & $\begin{array}{l}1.0 \\
0.0\end{array}$ & $\begin{array}{l}0.0 \\
0.1\end{array}$ & $\begin{array}{l}1.8 \\
2.4\end{array}$ & $\begin{array}{r}10.1 \\
0.0\end{array}$ & $\begin{array}{l}2.0 \\
1.3\end{array}$ & $\begin{array}{r}11.1 \\
0.2\end{array}$ & $\begin{array}{l}0.0 \\
0.1\end{array}$ \\
\hline 2 & $\begin{array}{l}\text { 雄別 } \\
\text { 炭礦鉄道 }\end{array}$ & 1,455 & 登 & $\begin{array}{l}16.7 \\
42.2\end{array}$ & $\begin{array}{l}2.0 \\
9.3\end{array}$ & $\begin{array}{l}0.5 \\
1.6\end{array}$ & $\begin{array}{l}0.0 \\
0.0\end{array}$ & $\begin{array}{l}0.0 \\
0.0\end{array}$ & 0.1 & $\begin{array}{l}3.6 \\
0.3\end{array}$ & $\begin{array}{l}1.1 \\
0.6\end{array}$ & $\begin{array}{r}13.2 \\
1.0\end{array}$ & $\begin{array}{l}0.1 \\
0.3\end{array}$ \\
\hline 3 & 十勝鉄道 & 60 & $\begin{array}{l}\text { 発 } \\
\text { 着 }\end{array}$ & $\begin{array}{r}0.2 \\
13.9\end{array}$ & $\begin{array}{l}3.8 \\
4.6\end{array}$ & $\begin{array}{l}0.8 \\
3.5\end{array}$ & $\begin{array}{l}0.0 \\
0.0\end{array}$ & 0.0 & - & $\begin{array}{l}0.0 \\
3.5\end{array}$ & $0 . \overline{1}$ & $\begin{array}{l}0.3 \\
0.3\end{array}$ & $\begin{array}{l}0.0 \\
0.0\end{array}$ \\
\hline 4 & $\begin{array}{l}\text { 北海道 } \\
\text { 拓列直鉄道 }\end{array}$ & 102 & 登 & $\begin{array}{l}0.1 \\
6.6\end{array}$ & $\begin{array}{r}40.8 \\
1.1\end{array}$ & $\begin{array}{l}3.5 \\
0.1\end{array}$ & $\begin{array}{l}0.1 \\
0.1\end{array}$ & $\begin{array}{l}0.3 \\
0.1\end{array}$ & $\overline{0.0}$ & $\begin{array}{l}0.1 \\
8.6\end{array}$ & $\overline{0.2}$ & $\begin{array}{r}0.0 \\
23.7\end{array}$ & $\begin{array}{l}0.4 \\
1.8\end{array}$ \\
\hline 5 & $\begin{array}{l}\text { 旭川 } \\
\text { 電気軌道 }\end{array}$ & 63 & 発 & $\begin{array}{r}0.2 \\
16.4\end{array}$ & $\begin{array}{l}7.9 \\
2.0\end{array}$ & $\begin{array}{r}11.7 \\
1.8\end{array}$ & $\begin{array}{l}0.3 \\
2.3\end{array}$ & $\begin{array}{l}0.0 \\
0.3\end{array}$ & $\overline{0.0}$ & $\begin{array}{r}0.1 \\
14.7\end{array}$ & $\begin{array}{r}3.6 \\
16.1\end{array}$ & $\begin{array}{l}0.5 \\
5.3\end{array}$ & $\begin{array}{l}0.1 \\
0.1\end{array}$ \\
\hline 6 & 留萠鉄道 & 706 & 登 & $\begin{array}{r}88.5 \\
3.0\end{array}$ & $\begin{array}{l}2.1 \\
4.2\end{array}$ & $\begin{array}{l}0.0 \\
0.4\end{array}$ & - & $\begin{array}{l}0.0 \\
0.0\end{array}$ & $\overline{0.0}$ & $\begin{array}{l}0.0 \\
0.1\end{array}$ & - & $\begin{array}{l}0.1 \\
0.3\end{array}$ & $\begin{array}{l}0.1 \\
0.1\end{array}$ \\
\hline 7 & 天塩鉄道 & 294 & 發 & $\begin{array}{r}52.9 \\
0.3\end{array}$ & $\begin{array}{r}31.9 \\
6.5\end{array}$ & $\begin{array}{l}0.2 \\
0.0\end{array}$ & $\begin{array}{l}0.0 \\
0.4\end{array}$ & $\begin{array}{l}0.4 \\
0.2\end{array}$ & - & $\overline{1.2}$ & - & $0 . \overline{4}$ & $\begin{array}{l}0.1 \\
0.2\end{array}$ \\
\hline 8 & $\begin{array}{l}\text { 羽瀑 } \\
\text { 炭礦鉄道 }\end{array}$ & 1,087 & 登 & $\begin{array}{r}94.0 \\
0.2\end{array}$ & $\begin{array}{l}1.3 \\
2.8\end{array}$ & $\begin{array}{l}0.0 \\
0.2\end{array}$ & $\overline{0.0}$ & $\begin{array}{l}0.0 \\
0.0\end{array}$ & 二 & $\begin{array}{l}0.0 \\
0.0\end{array}$ & $\overline{0.0}$ & $\begin{array}{l}0.0 \\
0.1\end{array}$ & $\begin{array}{l}0.0 \\
0.0\end{array}$ \\
\hline 9 & 美唄鉄道 & 2,361 & $\begin{array}{l}\text { 発 } \\
\text { 着 }\end{array}$ & $\begin{array}{r}93.5 \\
1.2\end{array}$ & $\begin{array}{l}0.2 \\
1.9\end{array}$ & $\begin{array}{l}0.0 \\
0.2\end{array}$ & 0.0 & - & - & - & $\overline{0.0}$ & $\begin{array}{l}0.0 \\
0.1\end{array}$ & $\begin{array}{l}0.0 \\
0.0\end{array}$ \\
\hline 10 & 定山渓鉄道 & 434 & $\begin{array}{l}\text { 発 } \\
\text { 着 }\end{array}$ & $\begin{array}{l}37.2 \\
17.0\end{array}$ & $\begin{array}{r}12.4 \\
4.9\end{array}$ & $\begin{array}{l}0.4 \\
0.3\end{array}$ & $\begin{array}{l}0.0 \\
0.0\end{array}$ & $\begin{array}{l}0.0 \\
0.0\end{array}$ & - & $0 . \overline{7}$ & $\overline{0.0}$ & $\begin{array}{l}0.1 \\
0.7\end{array}$ & $\begin{array}{l}0.1 \\
0.2\end{array}$ \\
\hline 11 & $\begin{array}{l}\text { 吾井鉱山 } \\
\text { 芦別道 }\end{array}$ & 1,339 & $\begin{array}{l}\text { 登 } \\
\text { 着 } \\
\text { 事 }\end{array}$ & $\begin{array}{r}90.0 \\
3.0\end{array}$ & $\begin{array}{l}1.3 \\
3.9\end{array}$ & $\begin{array}{l}0.0 \\
0.4\end{array}$ & $0 . \overline{0}$ & $\begin{array}{l}0.0 \\
0.0\end{array}$ & $\begin{array}{l}0.0 \\
0.0\end{array}$ & 0.0 & $\begin{array}{l}0.0 \\
0.0\end{array}$ & $\begin{array}{l}0.0 \\
0.4\end{array}$ & $\begin{array}{l}0.0 \\
0.0\end{array}$ \\
\hline 12 & 夕張鉄道 & 1,801 & 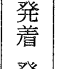 & $\begin{array}{l}67.8 \\
11.3\end{array}$ & $\begin{array}{l}1.8 \\
5.2\end{array}$ & $\begin{array}{l}1.1 \\
1.0\end{array}$ & $\begin{array}{l}0.2 \\
0.0\end{array}$ & $\begin{array}{l}0.0 \\
0.0\end{array}$ & $0 . \overline{0}$ & $\begin{array}{l}0.0 \\
1.1\end{array}$ & $\begin{array}{l}0.1 \\
0.2\end{array}$ & $\begin{array}{l}2.5 \\
0.5\end{array}$ & $\begin{array}{l}0.1 \\
0.1\end{array}$ \\
\hline 13 & 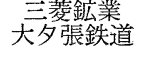 & 1,322 & $\begin{array}{l}\text { 登 } \\
\text { 着 }\end{array}$ & $\begin{array}{r}80.8 \\
0.6\end{array}$ & $\begin{array}{l}5.2 \\
4.0\end{array}$ & $\begin{array}{l}0.0 \\
0.8\end{array}$ & $\begin{array}{l}0.0 \\
0.0\end{array}$ & $\begin{array}{l}0.1 \\
0.0\end{array}$ & $\begin{array}{r}0.0 \\
0.1\end{array}$ & - & $\begin{array}{l}0.0 \\
0.0\end{array}$ & $\begin{array}{l}0.1 \\
0.9\end{array}$ & $\begin{array}{l}0.1 \\
0.0\end{array}$ \\
\hline 14 & 寿都鉄道 & 80 & $\begin{array}{l}\text { 登 } \\
\text { 着 } \\
\text { 茢 }\end{array}$ & $\begin{array}{l}0.6 \\
4.8\end{array}$ & $\begin{array}{r}19.6 \\
5.7\end{array}$ & $\begin{array}{l}5.3 \\
6.3\end{array}$ & $\begin{array}{l}0.1 \\
0.2\end{array}$ & $\begin{array}{l}0.1 \\
0.2\end{array}$ & $\begin{array}{r}10.6 \\
2.1\end{array}$ & $\begin{array}{l}0.3 \\
2.5\end{array}$ & $\begin{array}{l}0.1 \\
2.5\end{array}$ & $\begin{array}{l}0.4 \\
2.2\end{array}$ & $\begin{array}{l}0.1 \\
0.1\end{array}$ \\
\hline 15 & $\begin{array}{l}\text { 十和田 } \\
\text { 観光電鉄 }\end{array}$ & 156 & $\begin{array}{l}\text { 登 } \\
\text { 着 } \\
\text { 發 }\end{array}$ & $\begin{array}{l}0.2 \\
1.1\end{array}$ & $\begin{array}{r}16.8 \\
0.6\end{array}$ & $\begin{array}{r}16.3 \\
1.3\end{array}$ & $\begin{array}{l}0.0 \\
1.9\end{array}$ & $\begin{array}{l}3.1 \\
2.1\end{array}$ & $0 . \overline{0}$ & $\begin{array}{r}0.3 \\
26.6\end{array}$ & $\begin{array}{l}0.1 \\
1.0\end{array}$ & $\begin{array}{l}0.8 \\
7.8\end{array}$ & $\begin{array}{l}0.6 \\
1.4\end{array}$ \\
\hline 16 & 南部鉄道 & 111 & $\begin{array}{l}\text { 登 } \\
\text { 着 } \\
\text { 登 }\end{array}$ & $\begin{array}{l}0.0 \\
0.6\end{array}$ & $\begin{array}{r}36.6 \\
0.3\end{array}$ & $\begin{array}{r}20.2 \\
2.0\end{array}$ & $\overline{1.5}$ & $\begin{array}{l}1.2 \\
0.6\end{array}$ & 二 & $\begin{array}{r}0.2 \\
16.1\end{array}$ & $\begin{array}{l}0.1 \\
4.3\end{array}$ & $2 . \overline{7}$ & $\begin{array}{l}0.0 \\
0.1\end{array}$ \\
\hline 17 & 松尾鉱業 & 2,251 & $\begin{array}{l}\text { 發 } \\
\text { 着 }\end{array}$ & $\begin{array}{r}80.1 \\
7.2\end{array}$ & $0 . \overline{3}$ & $0 . \overline{0}$ & - & $\overline{0.0}$ & $0 . \overline{0}$ & $\overline{0.0}$ & $\overline{0.1}$ & $\begin{array}{l}0.0 \\
1.0\end{array}$ & $\begin{array}{l}0.0 \\
0.1\end{array}$ \\
\hline 18 & 津軽鉄道 & 68 & $\begin{array}{l}\text { 発 } \\
\text { 着 } \\
\text { 登 }\end{array}$ & $\begin{array}{l}0.3 \\
5.0\end{array}$ & $\begin{array}{r}18.2 \\
1.8\end{array}$ & $\begin{array}{r}36.9 \\
0.4\end{array}$ & $\begin{array}{l}0.0 \\
0.5\end{array}$ & $\begin{array}{l}0.7 \\
0.5\end{array}$ & $\overline{0.4}$ & $\begin{array}{r}0.2 \\
17.0\end{array}$ & $0 . \overline{1}$ & $\overline{6.8}$ & $\begin{array}{l}0.1 \\
0.2\end{array}$ \\
\hline 19 & 弘南鉄道 & 177 & 発 & $\begin{array}{l}0.9 \\
0.6\end{array}$ & $\begin{array}{r}2.0 \\
11.6\end{array}$ & $\begin{array}{r}44.6 \\
0.3\end{array}$ & $\overline{0.2}$ & $\begin{array}{l}0.4 \\
0.1\end{array}$ & $\begin{array}{l}0.0 \\
0.1\end{array}$ & $\begin{array}{l}0.1 \\
6.8\end{array}$ & $\begin{array}{l}0.1 \\
3.0\end{array}$ & $\begin{array}{l}0.1 \\
1.7\end{array}$ & $\begin{array}{l}0.0 \\
0.1\end{array}$ \\
\hline 20 & $\begin{array}{l}\text { 弘前 } \\
\text { 電気鉄道 }\end{array}$ & 35 & 発 & - & $\begin{array}{l}0.2 \\
4.1\end{array}$ & $\begin{array}{r}41.3 \\
3.7\end{array}$ & - & - & - & $\begin{array}{l}0.2 \\
7.6\end{array}$ & $\overline{0.1}$ & $\begin{array}{l}0.1 \\
2.6\end{array}$ & $\begin{array}{l}0.1 \\
0.3\end{array}$ \\
\hline 21 & 小坂鉄道 & 498 & 発 & $\begin{array}{r}68.1 \\
8.3\end{array}$ & $\overline{4.1}$ & $\begin{array}{l}0.0 \\
0.0\end{array}$ & $0 . \overline{0}$ & - & - & $0 . \overline{8}$ & $\begin{array}{l}2.4 \\
0.5\end{array}$ & $\overline{3.8}$ & $\begin{array}{l}0.1 \\
0.4\end{array}$ \\
\hline 22 & $\begin{array}{l}\text { 秋田 } \\
\text { 中央交通 }\end{array}$ & 66 & $\begin{array}{l}\text { 発 } \\
\text { 着 }\end{array}$ & $\overline{1.3}$. & $\begin{array}{l}57.5 \\
12.3\end{array}$ & $\begin{array}{l}9.1 \\
0.3\end{array}$ & $\begin{array}{l}0.1 \\
0.8\end{array}$ & $\begin{array}{l}0.7 \\
0.1\end{array}$ & $\overline{0.1}$ & $\begin{array}{l}0.1 \\
3.4\end{array}$ & - & $\begin{array}{l}0.1 \\
4.7\end{array}$ & $\overline{0.1}$ \\
\hline 23 & $\begin{array}{l}\text { 羽後交通 } \\
\text { (雄勝線) }\end{array}$ & 49 & 発 & $0 . \overline{5}$ & $\begin{array}{r}19.2 \\
2.5\end{array}$ & $\begin{array}{r}42.1 \\
0.6\end{array}$ & $\begin{array}{l}0.4 \\
3.1\end{array}$ & $\begin{array}{l}0.6 \\
0.3\end{array}$ & $\overline{0.3}$ & $16 . \overline{4}$ & $\overline{0.6}$ & $\begin{array}{l}0.1 \\
4.3\end{array}$ & $\begin{array}{l}0.0 \\
0.0\end{array}$ \\
\hline 24 & $\begin{array}{l}\text { 羽後交通 } \\
\text { (横荘線) }\end{array}$ & 75 & $\begin{array}{l}\text { 發 } \\
\text { 着 }\end{array}$ & $\begin{array}{l}0.0 \\
1.9\end{array}$ & $\begin{array}{l}4.7 \\
1.9\end{array}$ & $\begin{array}{r}50.5 \\
0.3\end{array}$ & $\begin{array}{l}1.2 \\
3.4\end{array}$ & $\begin{array}{l}0.3 \\
0.6\end{array}$ & $\overline{0.2}$ & $17 . \overline{8}$ & $\overline{0.4}$ & $\begin{array}{l}0.2 \\
5.7\end{array}$ & $\begin{array}{l}0.0 \\
0.1\end{array}$ \\
\hline 25 & $\begin{array}{l}\text { 山形交通 } \\
\text { (高鼻線) }\end{array}$ & 35 & $\begin{array}{l}\text { 発 } \\
\text { 着 }\end{array}$ & $\begin{array}{l}0.1 \\
8.3\end{array}$ & $\begin{array}{l}9.1 \\
0.3\end{array}$ & $\begin{array}{r}19.6 \\
0.4\end{array}$ & $\begin{array}{l}0.4 \\
4.8\end{array}$ & $\begin{array}{l}1.5 \\
1.0\end{array}$ & $\overline{-}$ & $\begin{array}{l}0.0 \\
6.1\end{array}$ & $\overline{1.0}$ & $\begin{array}{l}0.2 \\
6.6\end{array}$ & $\begin{array}{l}0.1 \\
0.1\end{array}$ \\
\hline 26 & $\begin{array}{l}\text { 山形交通 } \\
\text { (花沢線) }\end{array}$ & 54 & $\begin{array}{l}\text { 發 } \\
\text { 着 } \\
\end{array}$ & $\begin{array}{l}0.3 \\
0.2\end{array}$ & $\begin{array}{l}6.3 \\
1.2\end{array}$ & $\begin{array}{r}22.4 \\
0.8\end{array}$ & $\begin{array}{l}0.2 \\
1.2\end{array}$ & $\begin{array}{l}0.8 \\
0.9\end{array}$ & 3.8 & $\begin{array}{r}0.9 \\
29.3\end{array}$ & $\overline{0.5}$ & $\begin{array}{r}0.1 \\
11.2\end{array}$ & $\begin{array}{l}0.3 \\
0.2\end{array}$ \\
\hline 27 & $\begin{array}{l}\text { 山形交通 } \\
\text { (三山線) }\end{array}$ & 52 & $\begin{array}{l}\text { 発 } \\
\text { 着 }\end{array}$ & $\begin{array}{r}17.3 \\
1.3\end{array}$ & $\begin{array}{l}7.5 \\
4.9\end{array}$ & $\begin{array}{l}4.1 \\
0.6\end{array}$ & $\begin{array}{l}0.0 \\
0.5\end{array}$ & $\begin{array}{l}0.2 \\
0.3\end{array}$ & - & $\begin{array}{l}0.2 \\
6.1\end{array}$ & $\overline{0.2}$ & $\begin{array}{l}0.2 \\
9.9\end{array}$ & $\begin{array}{l}0.4 \\
1.6\end{array}$ \\
\hline 28 & $\begin{array}{l}\text { 栗原 } \\
\text { 電気鉄道 }\end{array}$ & 521 & $\begin{array}{l}\text { 発 } \\
\text { 着 }\end{array}$ & $\begin{array}{r}18.4 \\
5.2\end{array}$ & $\begin{array}{l}0.1 \\
0.2\end{array}$ & $\begin{array}{l}6.2 \\
0.1\end{array}$ & $0 . \overline{1}$ & $\begin{array}{l}0.3 \\
0.1\end{array}$ & $\overline{0.0}$ & $\begin{array}{l}0.0 \\
3.4\end{array}$ & $\begin{array}{r}11.2 \\
2.0\end{array}$ & 2.0 & $\begin{array}{l}0.1 \\
0.2\end{array}$ \\
\hline 29 & 仙北鉄道 & 69 & $\begin{array}{l}\text { 發 } \\
\text { 着 }\end{array}$ & $\begin{array}{l}0.0 \\
0.2\end{array}$ & $\overline{0.0}$ & $\begin{array}{r}42.3 \\
2.8\end{array}$ & $2 . \overline{6}$ & - & - & $\begin{array}{r}2.9 \\
37.2\end{array}$ & $\overline{1.2}$ & $\begin{array}{l}2.1 \\
0.5\end{array}$ & $\overline{0.6}$ \\
\hline 30 & 庄内交通 & 14 & $\begin{array}{l}\text { 発 } \\
\text { 着 }\end{array}$ & 0.4 & $\begin{array}{r}13.2 \\
5.7\end{array}$ & $\begin{array}{r}27.8 \\
0.7\end{array}$ & $\overline{0.3}$ & $\begin{array}{l}0.5 \\
0.2\end{array}$ & - & $\begin{array}{r}0.2 \\
22.6\end{array}$ & $\overline{14.6}$ & 5.8 & $\overline{0.2}$ \\
\hline
\end{tabular}


物品目別構成

\begin{tabular}{|c|c|c|c|c|c|c|c|c|c|c|c|c|c|}
\hline \multirow{2}{*}{$\begin{array}{c}\text { 農産加工品 } \\
\%\end{array}$} & \multirow{2}{*}{\begin{tabular}{|c|}
$\mid \begin{array}{c}\text { 繊維関係品 } \\
\%\end{array}$ \\
\end{tabular}} & \multirow{2}{*}{$\begin{array}{l}\text { パルプ } \\
\text { 紙類 \% }\end{array}$} & \multirow{2}{*}{ 菜工品 \% } & \multirow{2}{*}{ その他％ } & \multirow{2}{*}{ 合計比率 $\%$} & \multirow{2}{*}{ 合計トン数 } & \multirow{2}{*}{$\begin{array}{l}\text { 発着総詰 } \\
\text { トン数 }\end{array}$} & \multirow{2}{*}{$\mid$\begin{tabular}{c|}
$10 \%$ 以上を \\
占める品目名
\end{tabular}} & \multicolumn{4}{|c|}{ 各品目群の比率 } & \multirow{2}{*}{ 分颣 } \\
\hline & & & & & & & & & 1 & ㅁ & 八 & 計 & \\
\hline $\begin{array}{l}0.1 \\
1.6\end{array}$ & -- & - & $\begin{array}{l}1.4 \\
0.1\end{array}$ & $\begin{array}{l}3.6 \\
4.4\end{array}$ & $\begin{array}{l}60.2 \\
39.8\end{array}$ & $\begin{array}{l}274,352 \\
181,738\end{array}$ & 456,090 & $\begin{array}{l}\text { 石崖, セメント } \\
\text { 原木 }\end{array}$ & $\begin{array}{l}\% \\
5\end{array}$ & $\begin{array}{c}\% \\
57\end{array}$ & $\begin{array}{l}\% \\
37\end{array}$ & $\left|\begin{array}{r}\% \\
100\end{array}\right|$ & III \\
\hline$\overline{3.2}$ & E & $\overline{0.1}$ & $\begin{array}{l}0.2 \\
0.0\end{array}$ & $\begin{array}{l}1.6 \\
2.3\end{array}$ & $\begin{array}{l}39.1 \\
60.9\end{array}$ & $\begin{array}{l}194,181 \\
302,890\end{array}$ & 497,071 & $\begin{array}{l}\text { 石炭, セメント } \\
\text { 石炭 }\end{array}$ & 3 & 78 & 20 & 100 & III \\
\hline $\begin{array}{l}6.7 \\
0.1\end{array}$ & - & - & $\begin{array}{l}0.2 \\
0.4\end{array}$ & $\begin{array}{r}8.5 \\
53.1\end{array}$ & $\begin{array}{l}20.5 \\
79.5\end{array}$ & $\begin{array}{r}48,903 \\
189,288\end{array}$ & 238,191 & $\overline{\text { 石炭 }}$ & 8 & 21 & 71 & 100 & IV \\
\hline 0.0 & $\cdots$ & - & $\begin{array}{l}0.2 \\
1.0\end{array}$ & $\begin{array}{l}8.2 \\
2.9\end{array}$ & $\begin{array}{l}53.7 \\
46.3\end{array}$ & $\begin{array}{l}44,019 \\
37,911\end{array}$ & 81,930 & $\begin{array}{l}\text { 原木, 坑木 } \\
\text { セメント }\end{array}$ & 53 & 7 & 39 & 100 & I \\
\hline$\overline{0.1}$ & - & $\overline{0.0}$ & $\begin{array}{l}0.1 \\
0.1\end{array}$ & $\begin{array}{r}11.1 \\
5.3\end{array}$ & $\begin{array}{l}35.6 \\
64.4\end{array}$ & $\begin{array}{l}21,259 \\
38,353\end{array}$ & 59,612 & 类, & 35 & 37 & 28 & 100 & $\mathrm{IIb}$ \\
\hline$\overline{0.1}$ & - & - & $\begin{array}{l}0.0 \\
0.0\end{array}$ & $\begin{array}{l}0.3 \\
0.6\end{array}$ & $\begin{array}{r}91.2 \\
8.8\end{array}$ & $\begin{array}{r}278,085 \\
26,724\end{array}$ & 304,809 & 石炭 & 2 & 92 & 6 & 100 & III \\
\hline$\overline{0.0}$ & - & - & - & $\begin{array}{l}4.4 \\
0.8\end{array}$ & $\begin{array}{l}89.9 \\
10.1\end{array}$ & $\begin{array}{r}46,872 \\
5,271\end{array}$ & 52,143 & 石炭, 原木, 坑木 & 34 & 53 & 13 & 100 & Irb \\
\hline$\overline{0.1}$ & $\overline{-}$ & 二 & 0.0 & $\begin{array}{l}0.9 \\
0.2\end{array}$ & $\begin{array}{r}96.3 \\
3.7\end{array}$ & $\begin{array}{r}422,124 \\
16,291\end{array}$ & 438,415 & 石炭 & 1 & 94 & 4 & 100 & III \\
\hline $\begin{array}{l}0.0 \\
0.0\end{array}$ & - & - & $\begin{array}{l}0.0 \\
0.0\end{array}$ & $\begin{array}{l}1.8 \\
1.1\end{array}$ & $\begin{array}{r}95.5 \\
4.5\end{array}$ & $\begin{array}{r}1,009,872 \\
47,364\end{array}$ & $1,057,236$ & 石炭 & 0 & 95 & 5 & 100 & III \\
\hline $\begin{array}{l}0.1 \\
0.1\end{array}$ & - & - & $\overline{0.0}$ & $\begin{array}{r}16.8 \\
9.0\end{array}$ & $\begin{array}{l}67.0 \\
33.0\end{array}$ & $\begin{array}{r}127,673 \\
62,475\end{array}$ & 190,148 & 鉄鎕, 硫化鉱 & 14 & 55 & 32 & 100 & III \\
\hline $\begin{array}{l}0.0 \\
0.0\end{array}$ & - & - & 0.0 & $\begin{array}{l}0.4 \\
0.4\end{array}$ & $\begin{array}{r}91.8 \\
8.2\end{array}$ & $\begin{array}{r}622,001 \\
55,330\end{array}$ & 677,331 & 石炭 & 1 & 93 & 6 & 100 & DI \\
\hline $\begin{array}{l}0.1 \\
0.5\end{array}$ & - & $\overline{0.0}$ & $\begin{array}{l}0.0 \\
0.1\end{array}$ & $\begin{array}{l}4.3 \\
1.9\end{array}$ & $\begin{array}{l}78.1 \\
21.9\end{array}$ & $\begin{array}{l}577,693 \\
162,596\end{array}$ & 740,289 & 石炭 & 4 & 82 & 14 & 100 & III \\
\hline $\begin{array}{l}0.0 \\
0.2\end{array}$ & - & - & $\begin{array}{l}0.0 \\
0.0\end{array}$ & $\begin{array}{l}0.6 \\
6.4\end{array}$ & $\begin{array}{l}86.9 \\
13.1\end{array}$ & $\begin{array}{r}476,498 \\
72,003\end{array}$ & 548,501 & 石炭 & 5 & 82 & 13 & 100 & III \\
\hline $\begin{array}{l}0.0 \\
1.6\end{array}$ & - & $\overline{0.0}$ & $\overline{2.8}$ & $\begin{array}{r}27.2 \\
4.5\end{array}$ & $\begin{array}{l}64.5 \\
35.5\end{array}$ & $\begin{array}{l}20,089 \\
11,052\end{array}$ & 31,141 & 坑木 & 38 & 9 & 53 & 100 & I \\
\hline $\begin{array}{l}0.0 \\
2.7\end{array}$ & - & $\overline{0.0}$ & $\overline{0.6}$ & $\begin{array}{l}8.6 \\
6.0\end{array}$ & $\begin{array}{l}46.8 \\
53.2\end{array}$ & $\begin{array}{l}23,861 \\
27,098\end{array}$ & 50,959 & その他化学肥料 & 63 & 4 & 33 & 100 & I \\
\hline $\begin{array}{l}0.4 \\
1.7\end{array}$ & - & - & $\begin{array}{l}0.4 \\
0.2\end{array}$ & $\begin{array}{l}9.5 \\
1.3\end{array}$ & $\begin{array}{l}68.6 \\
31.4\end{array}$ & $\begin{array}{l}26,584 \\
12,136\end{array}$ & 38,720 & 製材，りんご & 74 & 6 & 20 & 100 & I \\
\hline$\overline{0.0}$ & - & - & $\overline{0.0}$ & $\begin{array}{l}9.4 \\
1.6\end{array}$ & $\begin{array}{l}89.7 \\
10.4\end{array}$ & $\begin{array}{r}731,953 \\
85,259\end{array}$ & 817,212 & 硫化鉱 & 0 & 87 & 12 & 100 & III \\
\hline$\overline{0.3}$ & 二 & - & 1.6 & $\begin{array}{l}7.3 \\
1.7\end{array}$ & $\begin{array}{l}65.2 \\
34.8\end{array}$ & $\begin{array}{l}22,154 \\
11,829\end{array}$ & 33,983 & 製材, 米, りんご & 73 & 6 & 22 & 100 & $I$ \\
\hline $\begin{array}{l}0.4 \\
0.3\end{array}$ & - & $\overline{0.0}$ & $\begin{array}{l}8.8 \\
0.2\end{array}$ & $\begin{array}{r}2.5 \\
15.1\end{array}$ & $\begin{array}{l}60.0 \\
40.0\end{array}$ & $\begin{array}{l}87,856 \\
58,701\end{array}$ & 146,557 & りんご & 54 & 5 & 41 & 100 & I \\
\hline$\overline{0.3}$ & - & $\overline{0.2}$ & $\overline{0.4}$ & $\begin{array}{l}11.2 \\
27.7\end{array}$ & $\begin{array}{l}53.1 \\
46.9\end{array}$ & $\begin{array}{l}8,272 \\
7,307\end{array}$ & 15,579 & りんご & 49 & 1 & 51 & 100 & I \\
\hline $\begin{array}{l}0.0 \\
0.0\end{array}$ & 二 & - & - & $\begin{array}{l}7.5 \\
4.2\end{array}$ & $\begin{array}{l}78.0 \\
22.0\end{array}$ & $\begin{array}{r}221,875 \\
62,577\end{array}$ & 284,452 & 硫化鉱 & 1 & 79 & 20 & 100 & III \\
\hline $\begin{array}{l}2.9 \\
1.1\end{array}$ & - & - & $\underline{0.8}$ & $\begin{array}{l}2.2 \\
2.2\end{array}$ & $\begin{array}{l}73.6 \\
26.4\end{array}$ & $\begin{array}{r}16,915 \\
6,064\end{array}$ & 22,979 & $\begin{array}{l}\text { 製材 } \\
\text { 原木 }\end{array}$ & 71 & 4 & 25 & 100 & I \\
\hline $\begin{array}{l}1.3 \\
0.5\end{array}$ & - & - & $\begin{array}{l}0.8 \\
0.2\end{array}$ & $\begin{array}{l}1.0 \\
5.2\end{array}$ & $\begin{array}{l}65.5 \\
34.5\end{array}$ & $\begin{array}{r}14,420 \\
7,574\end{array}$ & 21,994 & 製材, 米 & 79 & 3 & 19 & 100 & I \\
\hline $\begin{array}{l}0.9 \\
0.0\end{array}$ & $\overline{0.0}$ & E & $\begin{array}{l}1.9 \\
0.0\end{array}$ & $\begin{array}{l}0.5 \\
7.5\end{array}$ & $\begin{array}{l}60.2 \\
39.8\end{array}$ & $\begin{array}{l}26,465 \\
17,568\end{array}$ & 44,033 & 米 & 75 & 3 & 22 & 100 & I \\
\hline $\begin{array}{l}0.3 \\
1.2\end{array}$ & $\underline{0.2}$ & - & - & $\begin{array}{r}7.9 \\
30.9\end{array}$ & $\begin{array}{l}39.3 \\
60.7\end{array}$ & $\begin{array}{l}10,816 \\
16,692\end{array}$ & 27,508 & 米 & 37 & 10 & 53 & 100 & I \\
\hline$\underline{0.3}$ & $\underline{0.1}$ & - & $\begin{array}{l}0.2 \\
0.2\end{array}$ & $\begin{array}{r}14.2 \\
4.5\end{array}$ & $\begin{array}{l}46.0 \\
54.0\end{array}$ & $\begin{array}{l}8,489 \\
9,953\end{array}$ & 18,442 & $\begin{array}{l}\text { 米 } \\
\text { その他化学肥料 }\end{array}$ & 59 & 3 & 38 & 100 & I \\
\hline$\underline{0.9}$ & E & - & $\begin{array}{l}0.0 \\
0.0\end{array}$ & $\begin{array}{r}40.4 \\
3.3\end{array}$ & $\begin{array}{l}71.3 \\
28.7\end{array}$ & $\begin{array}{r}17,634 \\
7,091\end{array}$ & 24,725 & 硫化鉱 & 18 & 21 & 62 & 100 & IV \\
\hline $\begin{array}{l}0.0 \\
0.1\end{array}$ & - & - & $\begin{array}{l}0.2 \\
0.0\end{array}$ & $\begin{array}{l}28.1 \\
22.0\end{array}$ & $\begin{array}{l}64.6 \\
35.4\end{array}$ & $\begin{array}{r}130,974 \\
71,550\end{array}$ & 202,524 & 硫化鉱，硫酸 & 10 & 37 & 53 & 100 & III \\
\hline $\begin{array}{l}0.0 \\
4.9\end{array}$ & - & $\overline{0.0}$ & - & $\begin{array}{l}1.1 \\
1.4\end{array}$ & $\begin{array}{l}48.5 \\
51.5\end{array}$ & $\begin{array}{l}25,229 \\
26,821\end{array}$ & 52,050 & \begin{tabular}{|l} 
米 \\
その他化学肥料
\end{tabular} & 80 & 6 & 14 & 100 & I \\
\hline$\overline{0.2}$ & - & - & - & $\begin{array}{l}3.7 \\
4.0\end{array}$ & $\begin{array}{l}45.8 \\
54.2\end{array}$ & $\begin{array}{l}2,049 \\
2,423\end{array}$ & 4,472 & \begin{tabular}{|l|} 
坑木, 米 \\
その他化学 \\
肥料鉱油
\end{tabular} & 64 & 15 & 21 & 100 & I \\
\hline
\end{tabular}




\begin{tabular}{|c|c|c|c|c|c|c|c|c|c|c|c|c|c|}
\hline & 私 鉄 名 & $\begin{array}{l}\text { 貨物運 } \\
\text { 輸密度 }\end{array}$ & 登着 & $\begin{array}{l}\text { 鉱産関係 } \\
\text { 品 } \% \\
\end{array}$ & 林産品\% & 農産品\% & 飼料\% & 畜産品\% & 水産品\% & 肥料\% & $\begin{array}{l}\text { 鉱油・油脂· } \\
\text { 薬品類\% }\end{array}$ & 窯業品％ & 機械\% \\
\hline 31 & 蒲原鉄道 & $\begin{array}{l}\text { トン } \\
13\end{array}$ & $\begin{array}{l}\text { 発 } \\
\text { 着 }\end{array}$ & $\begin{array}{r}0.1 \\
20.6\end{array}$ & $\begin{array}{l}3.5 \\
5.3\end{array}$ & $\begin{array}{r}17.4 \\
0.5\end{array}$ & $\overline{0.2}$ & $\begin{array}{l}0.2 \\
0.2\end{array}$ & E & $19 . \overline{6}$ & $\overline{0.2}$ & $\begin{array}{l}2.0 \\
8.0\end{array}$ & $\begin{array}{l}0.0 \\
0.9\end{array}$ \\
\hline 32 & 新潟交通 & 99 & $\begin{array}{l}\text { 発 } \\
\text { 着 }\end{array}$ & $\begin{array}{l}0.1 \\
3.7\end{array}$ & $\begin{array}{l}0.0 \\
8.9\end{array}$ & $\begin{array}{r}32.2 \\
1.3\end{array}$ & $\begin{array}{l}0.4 \\
1.0\end{array}$ & $\begin{array}{l}2.9 \\
2.1\end{array}$ & 0.0 & $\begin{array}{r}0.3 \\
16.1\end{array}$ & $\begin{array}{l}4.6 \\
0.1\end{array}$ & $\begin{array}{l}1.4 \\
3.0\end{array}$ & 0.0 \\
\hline 33 & 長岡鉄道 & 82 & $\begin{array}{l}\text { 発 } \\
\text { 着 }\end{array}$ & $\begin{array}{r}40.6 \\
4.3\end{array}$ & $\begin{array}{l}0.3 \\
1.7\end{array}$ & $\begin{array}{r}14.2 \\
1.8\end{array}$ & $\begin{array}{l}0.1 \\
0.9\end{array}$ & $\begin{array}{l}0.6 \\
0.2\end{array}$ & $\overline{0.0}$ & $\begin{array}{l}0.2 \\
7.6\end{array}$ & $\begin{array}{l}0.3 \\
1.0\end{array}$ & $\begin{array}{r}0.7 \\
13.1\end{array}$ & $\begin{array}{l}0.2 \\
0.1\end{array}$ \\
\hline 34 & $\begin{array}{l}\text { 頸城 } \\
\text { 鉄道自動車 }\end{array}$ & 37 & $\begin{array}{l}\text { 発 } \\
\text { 着 }\end{array}$ & - & $\begin{array}{l}0.3 \\
0.1\end{array}$ & $\begin{array}{r}78.7 \\
0.7\end{array}$ & $\overline{1.7}$ & - & - & $12 \overline{0}$ & $\overline{0.1}$ & $\begin{array}{l}1.3 \\
1.0\end{array}$ & $\overline{0.1}$ \\
\hline 35 & 秩父鉄道 & 2,715 & $\begin{array}{l}\text { 発 } \\
\text { 着 }\end{array}$ & $\begin{array}{l}16.8 \\
19.4\end{array}$ & $\begin{array}{l}0.4 \\
0.7\end{array}$ & $\begin{array}{l}0.4 \\
0.7\end{array}$ & $\begin{array}{l}0.1 \\
0.1\end{array}$ & $\begin{array}{l}0.0 \\
0.0\end{array}$ & $\overline{0.0}$ & $\begin{array}{l}0.1 \\
1.2\end{array}$ & $\overline{0.4}$ & $\begin{array}{r}46.7 \\
1.1\end{array}$ & $\begin{array}{l}0.1 \\
0.0\end{array}$ \\
\hline 36 & $\begin{array}{l}\text { 日本ニッ } \\
\text { ケル鉄道 }\end{array}$ & 131 & $\begin{array}{l}\text { 発 } \\
\text { 着 }\end{array}$ & $\begin{array}{r}19.0 \\
1.2\end{array}$ & - & - & - & $\overline{0.0}$ & - & $\begin{array}{l}32.4 \\
31.8\end{array}$ & $\overline{0.0}$ & $\overline{1.3}$ & $\begin{array}{l}0.0 \\
0.1\end{array}$ \\
\hline 37 & 歯信 & 251 & $\begin{array}{l}\text { 発 } \\
\text { 着 }\end{array}$ & $\begin{array}{r}1.9 \\
13.8\end{array}$ & $\begin{array}{l}3.4 \\
1.1\end{array}$ & $\begin{array}{l}1.7 \\
2.5\end{array}$ & $\begin{array}{l}0.1 \\
0.6\end{array}$ & $\begin{array}{l}0.1 \\
0.5\end{array}$ & - & $\begin{array}{l}6.2 \\
8.9\end{array}$ & $\overline{0.1}$ & $\begin{array}{l}17.9 \\
14.7\end{array}$ & $\begin{array}{l}0.1 \\
0.2\end{array}$ \\
\hline 38 & 東武鉄道 & 1,267 & $\begin{array}{l}\text { 登 } \\
\text { 着 }\end{array}$ & $\begin{array}{l}18.6 \\
17.2\end{array}$ & $\begin{array}{l}0.5 \\
3.4\end{array}$ & $\begin{array}{l}2.2 \\
3.1\end{array}$ & $\begin{array}{l}0.5 \\
0.7\end{array}$ & $\begin{array}{l}0.0 \\
0.0\end{array}$ & $\begin{array}{l}0.0 \\
0.7\end{array}$ & $\begin{array}{l}1.7 \\
4.8\end{array}$ & $\begin{array}{l}0.1 \\
2.0\end{array}$ & $\begin{array}{l}6.1 \\
5.6\end{array}$ & $\begin{array}{l}0.1 \\
0.1\end{array}$ \\
\hline 39 & $\begin{array}{l}\text { 上毛 } \\
\text { 電気鉄道 }\end{array}$ & 30 & $\begin{array}{l}\text { 発 } \\
\text { 着 }\end{array}$ & $\begin{array}{l}0.3 \\
3.0\end{array}$ & $\begin{array}{l}0.9 \\
0.8\end{array}$ & $\begin{array}{l}4.1 \\
0.6\end{array}$ & $\begin{array}{l}8.4 \\
0.5\end{array}$ & 0.2 & - & $\begin{array}{r}4.8 \\
26.9\end{array}$ & $25 \overline{5}$ & $\begin{array}{l}0.2 \\
2.5\end{array}$ & $\begin{array}{l}0.1 \\
0.1\end{array}$ \\
\hline 40 & 東野鉄道 & 78 & $\begin{array}{l}\text { 発 } \\
\text { 着 }\end{array}$ & $\begin{array}{l}0.4 \\
4.0\end{array}$ & $\begin{array}{r}10.5 \\
0.2\end{array}$ & $\begin{array}{r}26.3 \\
0.9\end{array}$ & $2 . \overline{2}$ & $\begin{array}{l}0.6 \\
0.0\end{array}$ & $\overline{0.1}$ & $\begin{array}{r}0.0 \\
28.0\end{array}$ & $2 \overline{7}$ & $\begin{array}{l}0.5 \\
7.3\end{array}$ & $\overline{0.0}$ \\
\hline 41 & $\begin{array}{l}\text { 小名浜 } \\
\text { 臨港鉄道 }\end{array}$ & 917 & $\begin{array}{l}\text { 発 } \\
\text { 着 }\end{array}$ & $\begin{array}{r}2.9 \\
46.4\end{array}$ & $\begin{array}{l}0.0 \\
0.1\end{array}$ & $\overline{0.1}$ & $\begin{array}{l}0.0 \\
0.0\end{array}$ & - & $\begin{array}{l}5.9 \\
0.1\end{array}$ & $\begin{array}{r}25.2 \\
1.3\end{array}$ & $\begin{array}{l}1.7 \\
2.4\end{array}$ & $\begin{array}{l}0.0 \\
1.3\end{array}$ & $\begin{array}{l}0.0 \\
0.3\end{array}$ \\
\hline 42 & 江名鉄道 & 41 & $\begin{array}{l}\text { 發 } \\
\text { 着 }\end{array}$ & $6 . \overline{0}$ & $\overline{1.5}$ & - & - & - & $\begin{array}{r}70.4 \\
0.7\end{array}$ & $\begin{array}{l}0.2 \\
0.2\end{array}$ & 0.1 & $\begin{array}{l}0.1 \\
1.9\end{array}$ & $\begin{array}{l}0.4 \\
0.4\end{array}$ \\
\hline 43 & 日立電鉄 & 25 & $\begin{array}{l}\text { 発 } \\
\text { 着 }\end{array}$ & 24.6 & $\begin{array}{l}0.8 \\
0.6\end{array}$ & $\begin{array}{l}4.0 \\
0.1\end{array}$ & $\overline{4.8}$ & E & $\begin{array}{l}2.7 \\
0.1\end{array}$ & $\begin{array}{r}5.3 \\
25.0\end{array}$ & $\begin{array}{r}0.1 \\
18.2\end{array}$ & $2 \overline{8}$ & $\underline{0.0}$ \\
\hline 44 & $\begin{array}{l}\text { 茨城交通 } \\
\text { (茨城線) }\end{array}$ & 59 & $\begin{array}{l}\text { 発 } \\
\text { 着 }\end{array}$ & $\begin{array}{r}2.8 \\
27.2\end{array}$ & $\begin{array}{l}3.4 \\
0.1\end{array}$ & $\begin{array}{r}19.7 \\
1.5\end{array}$ & $\begin{array}{l}0.0 \\
1.5\end{array}$ & 0.0 & $\begin{array}{l}0.5 \\
7.7\end{array}$ & $\begin{array}{r}0.7 \\
13.4\end{array}$ & $\begin{array}{l}0.0 \\
3.1\end{array}$ & $\begin{array}{l}0.1 \\
4.1\end{array}$ & $\begin{array}{l}0.0 \\
0.0\end{array}$ \\
\hline 45 & $\begin{array}{l}\text { 茨城交通 } \\
\text { (湊 線) }\end{array}$ & 118 & 登 & $\begin{array}{l}0.6 \\
9.5\end{array}$ & $\begin{array}{l}0.2 \\
1.9\end{array}$ & $\begin{array}{r}15.7 \\
1.2\end{array}$ & $\begin{array}{l}0.0 \\
0.1\end{array}$ & - & $\begin{array}{r}23.8 \\
4.6\end{array}$ & $\begin{array}{r}0.4 \\
15.6\end{array}$ & $\overline{4.4}$ & $\begin{array}{l}0.4 \\
2.3\end{array}$ & $\begin{array}{l}0.5 \\
0.1\end{array}$ \\
\hline 46 & $\begin{array}{c}\text { 鹿島参宫鉄道 } \\
\text { (彥ヶ崎線) }\end{array}$ & 90 & $\begin{array}{l}\text { 登 } \\
\text { 着 }\end{array}$ & $\begin{array}{r}0.2 \\
14.6\end{array}$ & $\overline{1.6}$ & $\begin{array}{r}32.2 \\
3.6\end{array}$ & $\begin{array}{l}0.1 \\
1.8\end{array}$ & $\begin{array}{l}0.0 \\
0.0\end{array}$ & - & $\begin{array}{r}0.3 \\
34.4\end{array}$ & $\overline{0.0}$ & $\begin{array}{l}0.1 \\
7.0\end{array}$ & $\begin{array}{l}0.0 \\
0.2\end{array}$ \\
\hline 47 & $\begin{array}{c}\text { 鹿島参宮鉄道 } \\
\text { (鉾田線) }\end{array}$ & 169 & $\begin{array}{l}\text { 発 } \\
\text { 着 }\end{array}$ & $\overline{4.6}$ & $\begin{array}{l}3.9 \\
2.8\end{array}$ & $\begin{array}{r}21.5 \\
0.4\end{array}$ & $0 . \overline{3}$ & $\overline{0.0}$ & 0.0 & $\begin{array}{r}0.1 \\
37.3\end{array}$ & $\overline{1.4}$ & $\begin{array}{l}0.1 \\
7.4\end{array}$ & $\begin{array}{l}0.0 \\
0.0\end{array}$ \\
\hline 48 & $\begin{array}{c}\text { 常総筑波鉄道 } \\
\text { (常総線) }\end{array}$ & 243 & $\begin{array}{l}\text { 発 } \\
\text { 着 }\end{array}$ & $\begin{array}{r}11.7 \\
4.8\end{array}$ & $\begin{array}{l}0.7 \\
4.4\end{array}$ & $\begin{array}{r}30.9 \\
3.4\end{array}$ & $\begin{array}{l}0.6 \\
1.5\end{array}$ & $\begin{array}{l}0.0 \\
0.1\end{array}$ & - & $\begin{array}{r}0.7 \\
29.6\end{array}$ & $\begin{array}{l}0.0 \\
0.7\end{array}$ & $\begin{array}{l}0.0 \\
4.8\end{array}$ & $\begin{array}{l}0.0 \\
0.0\end{array}$ \\
\hline 49 & $\begin{array}{l}\text { 銚子 } \\
\text { 電気鉄道 }\end{array}$ & 11 & 発 & $\begin{array}{r}13.9 \\
7.1\end{array}$ & $0 . \overline{1}$ & $9 . \overline{9}$ & 1.8 & - & $\begin{array}{r}1.0 \\
31.2\end{array}$ & $\begin{array}{l}0.5 \\
7.6\end{array}$ & $\overline{3.5}$ & $\overline{7.3}$ & $\overline{0 . \overline{2}}$ \\
\hline 50 & 流山 & 88 & 登 & $\begin{array}{r}0.2 \\
16.6\end{array}$ & $2 . \overline{3}$ & $\begin{array}{r}1.5 \\
15.5\end{array}$ & $0 . \overline{0}$ & - & - & $\begin{array}{l}0.1 \\
7.7\end{array}$ & $\overline{7.4}$ & $\begin{array}{r}0.0 \\
16.1\end{array}$ & $\begin{array}{l}1.0 \\
0.2\end{array}$ \\
\hline 51 & $\begin{array}{l}\text { 西武鉄道 } \\
\text { (多摩川線) }\end{array}$ & 501 & $\begin{array}{l}\text { 発 } \\
\text { 着 }\end{array}$ & $\begin{array}{r}67.7 \\
1.5\end{array}$ & $2 \overline{6}$ & $\begin{array}{l}0.1 \\
0.2\end{array}$ & - & $\overline{0.0}$ & - & $0 . \overline{6}$ & - & $\begin{array}{l}0.8 \\
2.5\end{array}$ & $\overline{0.0}$ \\
\hline 52 & $\mid$\begin{tabular}{|} 
西武(新宿線 \\
鉄道(池袋線)
\end{tabular} & 528 & $\begin{array}{l}\text { 発 } \\
\text { 着 }\end{array}$ & $\begin{array}{l}20.7 \\
13.1\end{array}$ & $\begin{array}{l}0.2 \\
5.5\end{array}$ & $\begin{array}{r}3.1 \\
8.9\end{array}$ & $\begin{array}{l}0.6 \\
1.0\end{array}$ & - & - & $\begin{array}{l}1.3 \\
3.6\end{array}$ & $\begin{array}{l}0.0 \\
0.9\end{array}$ & $\begin{array}{l}1.4 \\
1.3\end{array}$ & $\begin{array}{l}0.2 \\
0.2\end{array}$ \\
\hline 53 & 小田急電鉄 & 343 & $\begin{array}{l}\text { 発 } \\
\text { 着 }\end{array}$ & $\begin{array}{l}13.0 \\
13.5\end{array}$ & $\begin{array}{r}0.2 \\
12.4\end{array}$ & $\begin{array}{l}16.3 \\
13.8\end{array}$ & $\begin{array}{l}2.5 \\
0.9\end{array}$ & $\begin{array}{l}0.1 \\
0.1\end{array}$ & - & $\begin{array}{l}0.4 \\
4.8\end{array}$ & - & $\begin{array}{l}1.1 \\
6.8\end{array}$ & $\begin{array}{l}0.0 \\
0.0\end{array}$ \\
\hline 54 & 相模鉄道 & 734 & $\begin{array}{l}\text { 発 } \\
\text { 着 }\end{array}$ & $\begin{array}{l}35.8 \\
15.7\end{array}$ & $\begin{array}{l}0.0 \\
2.6\end{array}$ & $\begin{array}{l}1.4 \\
0.8\end{array}$ & $\begin{array}{l}0.0 \\
0.0\end{array}$ & $\begin{array}{l}0.0 \\
0.0\end{array}$ & - & $\begin{array}{l}0.3 \\
0.2\end{array}$ & $\begin{array}{l}0.4 \\
0.1\end{array}$ & $\begin{array}{l}3.4 \\
1.7\end{array}$ & $\begin{array}{l}0.5 \\
0.0\end{array}$ \\
\hline 55 & $\begin{array}{l}\text { 富士麓電鉄 } \\
\end{array}$ & 160 & $\begin{array}{l}\text { 発 } \\
\text { 着 }\end{array}$ & $\begin{array}{l}4.7 \\
7.8\end{array}$ & $\begin{array}{r}16.6 \\
0.8\end{array}$ & $\begin{array}{r}2.9 \\
12.2\end{array}$ & $\begin{array}{l}2.3 \\
0.5\end{array}$ & $\begin{array}{l}0.0 \\
0.3\end{array}$ & 二 & $\begin{array}{l}0.0 \\
9.2\end{array}$ & $\begin{array}{l}0.0 \\
7.2\end{array}$ & $\begin{array}{l}1.1 \\
8.7\end{array}$ & $\begin{array}{l}0.1 \\
0.7\end{array}$ \\
\hline 56 & 長野電鉄 & 321 & $\begin{array}{l}\text { 発 } \\
\text { 着 }\end{array}$ & $\begin{array}{l}9.3 \\
9.2\end{array}$ & $\begin{array}{r}13.0 \\
3.2\end{array}$ & $\begin{array}{r}17.0 \\
2.8\end{array}$ & $\begin{array}{l}0.4 \\
1.0\end{array}$ & $\begin{array}{l}0.6 \\
0.1\end{array}$ & - & $\begin{array}{l}0.2 \\
6.5\end{array}$ & $\begin{array}{l}0.2 \\
0.1\end{array}$ & $\begin{array}{l}0.7 \\
8.5\end{array}$ & $\begin{array}{l}0.2 \\
0.2\end{array}$ \\
\hline 57 & $\begin{array}{l}\text { 松本 } \\
\text { 電気鉄道 }\end{array}$ & 74 & \begin{tabular}{|l} 
発 \\
着
\end{tabular} & $\begin{array}{l}1.1 \\
0.6\end{array}$ & $\begin{array}{r}62.4 \\
3.2\end{array}$ & $\begin{array}{l}2.1 \\
0.2\end{array}$ & $\begin{array}{l}0.1 \\
0.3\end{array}$ & $\begin{array}{l}0.7 \\
0.7\end{array}$ & - & $\begin{array}{r}0.2 \\
10.4\end{array}$ & $\begin{array}{l}0.1 \\
0.3\end{array}$ & $\begin{array}{l}0.1 \\
6.6\end{array}$ & $\begin{array}{l}0.6 \\
0.4\end{array}$ \\
\hline 58 & 駿豆鉄道 & 251 & $\begin{array}{l}\text { 発 } \\
\text { 着 }\end{array}$ & $\begin{array}{l}3.4 \\
9.5\end{array}$ & $\begin{array}{l}0.5 \\
1.4\end{array}$ & $\begin{array}{r}0.7 \\
15.5\end{array}$ & $\begin{array}{l}0.0 \\
0.6\end{array}$ & $\begin{array}{l}0.4 \\
0.1\end{array}$ & - & $\overline{4.5}$ & $\begin{array}{l}0.0 \\
1.2\end{array}$ & $\begin{array}{r}0.2 \\
17.9\end{array}$ & $\begin{array}{l}0.2 \\
0.2\end{array}$ \\
\hline 59 & 岳南鉄道 & 684 & \begin{tabular}{|l} 
発 \\
着
\end{tabular} & $\begin{array}{r}0.1 \\
23.5\end{array}$ & $\begin{array}{r}0.0 \\
14.8\end{array}$ & $\begin{array}{l}0.5 \\
1.8\end{array}$ & $\overline{0.0}$ & $\begin{array}{l}0.0 \\
0.0\end{array}$ & $0 . \overline{0}$ & $0 . \overline{6}$ & $\begin{array}{l}0.0 \\
1.6\end{array}$ & $\begin{array}{l}0.1 \\
3.7\end{array}$ & $\begin{array}{l}0.1 \\
0.2\end{array}$ \\
\hline 60 & 大井川鉄道 & 534 & \begin{tabular}{|l} 
発 \\
着
\end{tabular} & $\begin{array}{l}0.8 \\
4.0\end{array}$ & $\begin{array}{r}19.6 \\
7.6\end{array}$ & $\begin{array}{l}0.2 \\
1.0\end{array}$ & $\overline{0.0}$ & $0 . \overline{0}$ & - & $\overline{1.4}$ & $\begin{array}{l}0.0 \\
1.0\end{array}$ & $\begin{array}{r}0.1 \\
50.0\end{array}$ & $\begin{array}{l}0.8 \\
0.6\end{array}$ \\
\hline 61 & $\begin{array}{l}\text { 静岡鉄道 } \\
\text { (駿遠線) }\end{array}$ & 45 & \begin{tabular}{|l} 
発 \\
㠊
\end{tabular} & $0 . \overline{9}$ & $\begin{array}{l}0.1 \\
2.0\end{array}$ & $\begin{array}{l}6.4 \\
4.4\end{array}$ & $\begin{array}{l}0.0 \\
4.6\end{array}$ & - & - & $\begin{array}{r}0.2 \\
44.2\end{array}$ & $0 . \overline{1}$ & $\begin{array}{r}0.7 \\
11.6\end{array}$ & $\overline{0.1}$ \\
\hline
\end{tabular}




\begin{tabular}{|c|c|c|c|c|c|c|c|c|c|c|c|c|c|}
\hline \multirow{2}{*}{$\begin{array}{c}\begin{array}{c}\text { 農産加工品 } \\
\%\end{array} \\
\end{array}$} & \multirow{2}{*}{ 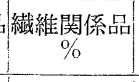 } & \multirow{2}{*}{$\begin{array}{l}\text { パルプ } \\
\text { 紙類 \% }\end{array}$} & \multirow{2}{*}{ 蔡工品\% } & \multirow{2}{*}{ その他\% } & \multirow{2}{*}{ 合計比率\% } & \multirow{2}{*}{ 合計トン数 } & \multirow{2}{*}{$\begin{array}{l}\text { 発着総計 } \\
\text { 卜数 }\end{array}$} & \multirow{2}{*}{$\mid$\begin{tabular}{c|}
$10 \%$ 以上を \\
占める品目名
\end{tabular}} & \multicolumn{4}{|c|}{ 各品目群の比率 } & \multirow{2}{*}{ 分類 } \\
\hline & & & & & & & & & 1 & 口 & 八 & 計 & \\
\hline $\begin{array}{l}0.1 \\
2.6\end{array}$ & $0 . \overline{1}$ & - & - & $\begin{array}{r}11.1 \\
7.5\end{array}$ & $\begin{array}{l}34.4 \\
65.6\end{array}$ & $\begin{array}{r}5,839 \\
11,130\end{array}$ & 16,969 & 9 鋼校, zの他, & $41 \%$ & 23 & $\begin{array}{l}\% \\
36\end{array}$ & $\begin{array}{r}\% \\
100\end{array}$ & \begin{tabular}{l|l}
0 & $\mathrm{IIa}$ \\
0 & $\mathrm{IIa}$
\end{tabular} \\
\hline $\begin{array}{l}0.0 \\
1.5\end{array}$ & 0.0 & $\begin{array}{l}0.8 \\
0.1\end{array}$ & $\begin{array}{l}6.6 \\
0.0\end{array}$ & $\begin{array}{l}6.0 \\
6.7\end{array}$ & $\begin{array}{l}55.4 \\
44.6\end{array}$ & $\begin{array}{l}33,915 \\
27,302\end{array}$ & 61,217 & 7 米の他化学肥料 & 52 & 11 & 37 & 100 & $0 \quad I$ \\
\hline $\begin{array}{l}0.9 \\
2.5\end{array}$ & 0.0 & $\begin{array}{l}0.1 \\
0.1\end{array}$ & $\begin{array}{l}2.8 \\
0.0\end{array}$ & $\begin{array}{l}2.6 \\
3.2\end{array}$ & $\begin{array}{l}63.5 \\
36.5\end{array}$ & $\begin{array}{l}46,399 \\
26,637\end{array}$ & 73,036 & 6砂利及び砂, & 23 & 48 & 29 & 100 & 0 III \\
\hline $\begin{array}{l}0.3 \\
0.9\end{array}$ & - & - & 0.1 & $\begin{array}{l}1.6 \\
1.2\end{array}$ & $\begin{array}{l}82.2 \\
17.8\end{array}$ & $\begin{array}{r}10,251 \\
2,220\end{array}$ & 12,471 & 米 & 91 & 2 & 7 & 100 & $0 \mid \mathrm{I}$ \\
\hline $\begin{array}{l}0.0 \\
0.0\end{array}$ & $\begin{array}{l}0.0 \\
0.0\end{array}$ & $\overline{0.1}$ & $\begin{array}{l}0.0 \\
0.0\end{array}$ & $\begin{array}{l}5.3 \\
6.4\end{array}$ & $\begin{array}{l}69.8 \\
30.2\end{array}$ & $\begin{array}{r}1,224,176 \\
528,506\end{array}$ & $1,752,682$ & 2 石灰石, セメント & 2 & 84. & 14 & 100 & 0 III \\
\hline - & $\overline{-}$ & - & $\begin{array}{l}0.2 \\
0.2\end{array}$ & $\begin{array}{r}0.3 \\
13.5\end{array}$ & $\begin{array}{l}51.9 \\
48.1\end{array}$ & $\begin{array}{l}51,344 \\
47,641\end{array}$ & 98,985 & 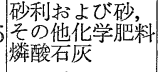 & 32 & 53 & 16 & 100 & IIb \\
\hline$\overline{0.1}$ & $\begin{array}{l}0.3 \\
0.5\end{array}$ & $\overline{0.1}$ & $\overline{0.1}$ & $\begin{array}{r}16.9 \\
8.3\end{array}$ & $\begin{array}{l}48.5 \\
51.5\end{array}$ & $\begin{array}{l}57,347 \\
60,744\end{array}$ & 118,091 & $\begin{array}{l}\text { 石灰 } \\
\text { セメント }\end{array}$ & 14 & 40 & 46 & 100 & III \\
\hline $\begin{array}{l}3.3 \\
0.4\end{array}$ & $\begin{array}{l}0.1 \\
0.2\end{array}$ & $\begin{array}{l}0.1 \\
0.2\end{array}$ & $\begin{array}{l}0.1 \\
0.0\end{array}$ & $\begin{array}{r}19.8 \\
8.3\end{array}$ & $\begin{array}{l}53.1 \\
46.9\end{array}$ & $\begin{array}{l}2,583,502 \\
2,279,447\end{array}$ & $4,862,949$ & 砂利および砂 & 8 & 49 & 43 & 100 & III \\
\hline$\underline{0.7}$ & $\underline{0.4}$ & - & $\overline{0.0}$ & $\begin{array}{r}12.5 \\
7.5\end{array}$ & $\begin{array}{l}32.6 \\
67.4\end{array}$ & $\begin{array}{r}8,092 \\
16,710\end{array}$ & 24,802 & $=$ & 41 & 35 & 25 & 100 & IIb \\
\hline $\begin{array}{l}0.1 \\
0.7\end{array}$ & - & $\overline{-}$ & $\overline{0.6}$ & $\begin{array}{r}13.2 \\
1.7\end{array}$ & $\begin{array}{l}51.7 \\
48.3\end{array}$ & $\begin{array}{l}22,820 \\
21,288\end{array}$ & 44,108 & $3 \mid \begin{array}{l}\text { 米 } \\
\text { その他化学肥料 }\end{array}$ & 65 & 8 & 27 & 100 & I \\
\hline $\begin{array}{l}0.0 \\
0.1\end{array}$ & - & - & $\begin{array}{l}0.0 \\
0.2\end{array}$ & $\begin{array}{l}3.3 \\
8.7\end{array}$ & $\begin{array}{l}39.1 \\
60.9\end{array}$ & $\begin{array}{l}198,206 \\
308,455\end{array}$ & 506,661 & 硫酸アンモニア 硫化鉱 & 7 & 79 & 14 & 100 & IIII \\
\hline $\begin{array}{l}0.1 \\
0.4\end{array}$ & 二 & $\underline{-}$ & - & $\begin{array}{r}3.2 \\
14.6\end{array}$ & $\begin{array}{l}74.4 \\
25.6\end{array}$ & $\begin{array}{r}12,242 \\
4,201\end{array}$ & 16,443 & 鮮魚冷凍魚 & 71 & 7 & 23 & 100 & I \\
\hline $0 . \overline{1}$ & - & E & 0.3 & $\begin{array}{l}9.8 \\
0.8\end{array}$ & $\begin{array}{l}47.6 \\
52.4\end{array}$ & $\begin{array}{l}8,285 \\
9,122\end{array}$ & 17, & $\begin{array}{l}\text { 石炭石 } \\
\text { 学の他化学肥 } \\
\text { 料, 鉱油 }\end{array}$ & 33 & 48 & 19 & 100 & IIb \\
\hline $\begin{array}{l}0.0 \\
0.2\end{array}$ & - & - & $\begin{array}{l}0.1 \\
0.0\end{array}$ & $\begin{array}{r}10.4 \\
3.3\end{array}$ & $\begin{array}{l}37.8 \\
62.2\end{array}$ & $\begin{array}{l}22,907 \\
37,679\end{array}$ & 60,586 & $\frac{\text { 石炭 }}{4}$ & 37 & 34 & 29 & 100 & IIb \\
\hline $\begin{array}{l}0.1 \\
0.3\end{array}$ & - & 0.0 & $\begin{array}{l}0.1 \\
0.4\end{array}$ & $\begin{array}{r}14.5 \\
3.3\end{array}$ & $\begin{array}{l}56.3 \\
43.7\end{array}$ & $\begin{array}{l}37,249 \\
28,944\end{array}$ & 66,193 & 甘諸鮮魚冷東魚 & 55 & 16 & 29 & 100 & I \\
\hline 0.3 & - & - & - & $\begin{array}{l}1.0 \\
2.5\end{array}$ & $\begin{array}{l}34.0 \\
66.0\end{array}$ & $\begin{array}{l}10,930 \\
21,266\end{array}$ & 32,196 & 类 & 67 & 15 & 18 & 100 & I \\
\hline $\begin{array}{l}0.0 \\
0.3\end{array}$ & $\overline{0.0}$ & - & $\begin{array}{l}3.1 \\
0.0\end{array}$ & $\begin{array}{r}15.7 \\
1.1\end{array}$ & $\begin{array}{l}44.4 \\
55.6\end{array}$ & $\begin{array}{l}33,809 \\
42,463\end{array}$ & 76,272 & 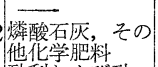 & 63 & 6 & 31 & 100 & I \\
\hline $\begin{array}{l}0.0 \\
0.2\end{array}$ & $\begin{array}{l}0.1 \\
0.0\end{array}$ & $\overline{0.0}$ & $\underline{0.1}$ & $\begin{array}{l}1.6 \\
3.8\end{array}$ & $\begin{array}{l}46.6 \\
53.4\end{array}$ & $\begin{array}{l}81,589 \\
93,534\end{array}$ & 175,123 & 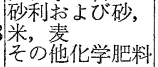 & 62 & 18 & 20 & 100 & I \\
\hline$\underline{0.9}$ & - & - & - & $\begin{array}{r}2.7 \\
12.3\end{array}$ & $\begin{array}{l}20.8 \\
79.2\end{array}$ & $\begin{array}{l}2,104 \\
8,009\end{array}$ & 10,111 & 砂利抢よび砂 & 10 & 26 & 64 & 100 & IV \\
\hline $\begin{array}{r}23.5 \\
0.3\end{array}$ & E & - & $\begin{array}{l}0.4 \\
0.0\end{array}$ & $\begin{array}{l}5.9 \\
1.3\end{array}$ & $\begin{array}{l}32.5 \\
67.5\end{array}$ & $\begin{array}{r}9,074 \\
18,902\end{array}$ & 27,976 & $\begin{array}{l}\text { 酒 } \\
\text { 㳅炭, ガ嚄, 鉱 }\end{array}$ & 9 & 49 & 42 & 100 & III \\
\hline$\overline{0.9}$ & - & $\overline{0.1}$ & - & $\begin{array}{r}9.2 \\
13.8\end{array}$ & $\begin{array}{l}77.8 \\
22.8\end{array}$ & $\begin{array}{l}85,980 \\
24,523\end{array}$ & 110,503 & 砂利および砂 & 1 & 70 & 29 & 100 & III \\
\hline $\begin{array}{l}0.8 \\
0.9\end{array}$ & $\begin{array}{l}0.3 \\
0.7\end{array}$ & $\begin{array}{l}0.0 \\
0.0\end{array}$ & 0.0 & $\begin{array}{l}12.1 \\
23.3\end{array}$ & $\begin{array}{l}40.7 \\
59.3\end{array}$ & $\begin{array}{l}229,307 \\
334,608\end{array}$ & 563,915 & 砂利および砂 & 8 & 39 & 54 & 100 & III \\
\hline $\begin{array}{l}1.5 \\
0.3\end{array}$ & $\overline{0.0}$ & $\begin{array}{l}0.0 \\
0.0\end{array}$ & 0.2 & $\begin{array}{l}3.2 \\
8.9\end{array}$ & $\begin{array}{l}38.4 \\
61.6\end{array}$ & $\begin{array}{l}36,531 \\
58,602\end{array}$ & 95,133 & 砂利及び砂，表 & 24 & 30 & 47 & 100 & IIc \\
\hline $\begin{array}{l}0.0 \\
0.0\end{array}$ & $\overline{0.1}$ & $\begin{array}{l}0.0 \\
0.1\end{array}$ & $\begin{array}{l}0.0 \\
0.0\end{array}$ & $\begin{array}{l}12.2 \\
24.6\end{array}$ & $\begin{array}{l}54.1 \\
45.9\end{array}$ & $\begin{array}{r}246,123 \\
\quad 208,755\end{array}$ & 454,878 & 砂利抢よび砂 & 2 & 56 & 42 & 100 & III \\
\hline $\begin{array}{l}0.0 \\
5.1\end{array}$ & $\begin{array}{l}0.3 \\
0.4\end{array}$ & $\begin{array}{l}3.9 \\
2.1\end{array}$ & $\begin{array}{l}0.0 \\
0.0\end{array}$ & $\begin{array}{l}7.8 \\
5.1\end{array}$ & $\begin{array}{l}39.8 \\
60.2\end{array}$ & $\begin{array}{l}31,035 \\
47,112\end{array}$ & 78,147 & 坑木 & 31 & 25 & 44 & 100 & $\mathrm{IIa}$ \\
\hline $\begin{array}{l}0.0 \\
0.7\end{array}$ & $\begin{array}{l}0.1 \\
0.1\end{array}$ & $\begin{array}{l}2.2 \\
0.0\end{array}$ & $\begin{array}{l}0.0 \\
0.3\end{array}$ & $\begin{array}{r}14.8 \\
8.5\end{array}$ & $\begin{array}{l}58.7 \\
41.3\end{array}$ & $\begin{array}{l}183,132 \\
128,872\end{array}$ & 312,004 & りんご & 38 & 22 & 40 & 100 & IIa \\
\hline $\begin{array}{l}0.1 \\
0.1\end{array}$ & - & - & $\overline{0.1}$ & $\begin{array}{l}4.3 \\
5.4\end{array}$ & $\begin{array}{l}71.8 \\
28.2\end{array}$ & $\begin{array}{l}28,631 \\
11,236\end{array}$ & 39,867 & 原木, 坑木 & 76 & 3 & 21 & 100 & I \\
\hline $\begin{array}{r}16.6 \\
1.0\end{array}$ & - & $\begin{array}{l}0.0 \\
0.0\end{array}$ & $\begin{array}{l}0.1 \\
0.2\end{array}$ & $\begin{array}{l}10.5 \\
15.4\end{array}$ & $\begin{array}{l}32.6 \\
67.4\end{array}$ & $\begin{array}{l}41,462 \\
85,642\end{array}$ & 127,104 & 酒势 & 6 & 31 & 63 & 100 & III \\
\hline $\begin{array}{l}1.5 \\
0.2\end{array}$ & - & $\begin{array}{l}15.1 \\
19.7\end{array}$ & $\begin{array}{l}0.0 \\
0.3\end{array}$ & $\begin{array}{r}2.7 \\
13.7\end{array}$ & $\begin{array}{l}19.9 \\
80.1\end{array}$ & $\begin{array}{l}101,290 \\
407,786\end{array}$ & 509,0 & 紙 & 1 & 42 & 57 & 100 & III \\
\hline$\overline{0.0}$ & - & $\overline{-}$ & $\overline{0.0}$ & $\begin{array}{l}4.0 \\
9.0\end{array}$ & $\begin{array}{l}25.5 \\
74.5\end{array}$ & $\begin{array}{r}44,239 \\
129,543\end{array}$ & 173,782 & セメント & 21 & 7 & 72 & 100 & IV \\
\hline $\begin{array}{l}2.3 \\
0.8\end{array}$ & 0.0 & 0.0 & $\begin{array}{l}0.0 \\
0.0\end{array}$ & $\begin{array}{l}10.1 \\
11.4\end{array}$ & $\begin{array}{l}20.0 \\
80.0\end{array}$ & $\begin{array}{r}8,953 \\
35,764\end{array}$ & 44,717 & $\mid \begin{array}{l}\text { その他化学肥料 } \\
\text { セメント }\end{array}$ & 51 & 4 & 45 & 100 & I \\
\hline
\end{tabular}




\begin{tabular}{|c|c|c|c|c|c|c|c|c|c|c|c|c|c|}
\hline & 私 鉄名 & $\begin{array}{l}\text { 貨物運 } \\
\text { 輸密山度 }\end{array}$ & $\mid$ & $\begin{array}{l}\text { 鉱産関係 } \\
\text { 品 }\end{array}$ & 林産品\% & 農産品\% & 飼料\% & 畜産品\% & 6 水産品\% & 肥料 \% & $\begin{array}{l}\text { 鉱油・油脂· } \\
\text { 薬品類\% }\end{array}$ & ·窯業品\% & 機械\% \\
\hline 62 & $\begin{array}{l}\text { 遠州鉄道 } \\
\text { (二俣線) }\end{array}$ & $\begin{array}{l}\text { トン } \\
148\end{array}$ & $\begin{array}{l}\text { 發 } \\
\text { 着 }\end{array}$ & $\begin{array}{r}0.6 \\
27.2\end{array}$ & $\begin{array}{l}4.7 \\
7.0\end{array}$ & $\begin{array}{l}3.7 \\
3.1\end{array}$ & $\begin{array}{l}0.0 \\
1.9\end{array}$ & 0.2 & - & $\begin{array}{l}0.1 \\
6.1\end{array}$ & $\begin{array}{r}0.1 \\
15.3\end{array}$ & $\begin{array}{l}1.4 \\
3.4\end{array}$ & $\begin{array}{l}0.1 \\
0.1\end{array}$ \\
\hline 63 & $\begin{array}{l}\text { 豊橋鉄道 } \\
\text { (渥美線) }\end{array}$ & 228 & $\begin{array}{l}\text { 発 } \\
\text { 着 }\end{array}$ & $\begin{array}{r}0.2 \\
31.2\end{array}$ & $\begin{array}{l}0.4 \\
1.4\end{array}$ & $\begin{array}{l}4.4 \\
1.0\end{array}$ & $\begin{array}{l}1.5 \\
2.0\end{array}$ & $0 . \overline{0}$ & $\overline{0.2}$ & $\begin{array}{l}0.9 \\
6.3\end{array}$ & $\overline{0.4}$ & $\begin{array}{r}26.0 \\
1.1\end{array}$ & $\begin{array}{l}0.1 \\
0.1\end{array}$ \\
\hline 64 & $\begin{array}{l}\text { 豊橋鉄道 } \\
\text { (田口線) }\end{array}$ & 57 & $\begin{array}{l}\text { 発 } \\
\text { 着 }\end{array}$ & $\begin{array}{r}46.6 \\
0.2\end{array}$ & $\begin{array}{r}40.9 \\
1.3\end{array}$ & $\begin{array}{l}0.0 \\
0.8\end{array}$ & - & 0.1 & - & $\overline{1.3}$ & $\overline{0.5}$ & $\overline{2.6}$ & $\begin{array}{l}0.1 \\
0.0\end{array}$ \\
\hline 65 & 名古屋鉄道 & 356 & $\begin{array}{l}\text { 発 } \\
\text { 着 }\end{array}$ & $\begin{array}{r}6.4 \\
13.7\end{array}$ & $\begin{array}{l}0.9 \\
5.6\end{array}$ & $\begin{array}{l}1.7 \\
1.4\end{array}$ & $\begin{array}{l}0.7 \\
0.7\end{array}$ & $\begin{array}{l}0.2 \\
0.2\end{array}$ & $\begin{array}{l}0.1 \\
0.1\end{array}$ & $\begin{array}{l}2.3 \\
2.9\end{array}$ & $\begin{array}{l}3.0 \\
2.4\end{array}$ & $\begin{array}{r}10.5 \\
3.5\end{array}$ & $\begin{array}{l}0.6 \\
0.3\end{array}$ \\
\hline 66 & 北恵那鉄道 & 64 & $\begin{array}{l}\text { 發 } \\
\text { 着 }\end{array}$ & $\begin{array}{r}20.6 \\
2.9\end{array}$ & $\begin{array}{r}16.0 \\
1.0\end{array}$ & $\begin{array}{l}0.2 \\
0.4\end{array}$ & $\overline{0.2}$ & 0.0 & - & $\begin{array}{l}0.1 \\
4.8\end{array}$ & $\begin{array}{l}0.1 \\
0.9\end{array}$ & $\overline{5.4}$ & $\begin{array}{l}0.1 \\
0.1\end{array}$ \\
\hline 67 & 西濃鉄道 & 527 & $\begin{array}{l}\text { 発 } \\
\text { 着 }\end{array}$ & $\begin{array}{l}19.2 \\
20.1\end{array}$ & $\overline{0.1}$ & $\begin{array}{l}0.0 \\
0.0\end{array}$ & - & - & - & $\begin{array}{l}0.6 \\
0.0\end{array}$ & - & $\begin{array}{r}55.0 \\
0.2\end{array}$ & $\overline{0.0}$ \\
\hline 68 & 東濃鉄道 & 138 & \begin{tabular}{|l} 
発 \\
着
\end{tabular} & $\begin{array}{r}0.0 \\
18.6\end{array}$ & $\begin{array}{l}0.0 \\
2.4\end{array}$ & $\begin{array}{l}0.0 \\
3.7\end{array}$ & $\overline{0.1}$ & $\overline{-}$ & - & $\overline{0.5}$ & $\overline{1.1}$ & $\begin{array}{r}22.0 \\
1.7\end{array}$ & $\begin{array}{l}0.0 \\
0.1\end{array}$ \\
\hline 69 & 三岐鉄道 & 1,551 & \begin{tabular}{|l|} 
発 \\
着
\end{tabular} & $\begin{array}{l}11.1 \\
19.8\end{array}$ & $\begin{array}{l}0.0 \\
0.1\end{array}$ & $\begin{array}{l}0.9 \\
0.1\end{array}$ & $\begin{array}{l}0.2 \\
0.0\end{array}$ & $\begin{array}{l}0.0 \\
0.1\end{array}$ & - & $\begin{array}{l}0.1 \\
0.4\end{array}$ & $\overline{0 . \overline{1}}$ & $\begin{array}{r}59.1 \\
0.2\end{array}$ & $\begin{array}{l}0.0 \\
0.0\end{array}$ \\
\hline 70 & 近江鉄道 & 69 & \begin{tabular}{|l|} 
発 \\
着
\end{tabular} & $\begin{array}{r}28.2 \\
2.4\end{array}$ & $\begin{array}{l}9.0 \\
0.8\end{array}$ & $\begin{array}{r}12.8 \\
1.4\end{array}$ & $\begin{array}{l}0.1 \\
2.0\end{array}$ & $\begin{array}{l}1.0 \\
0.2\end{array}$ & $\overline{0.0}$ & $\begin{array}{r}0.2 \\
15.2\end{array}$ & $\begin{array}{l}0.0 \\
0.0\end{array}$ & $\begin{array}{l}0.1 \\
4.9\end{array}$ & $\begin{array}{l}0.1 \\
0.1\end{array}$ \\
\hline 71 & $\begin{array}{l}\text { 近畿 } \\
\text { 日本鉄道 }\end{array}$ & 85 & \begin{tabular}{|l|} 
発 \\
着
\end{tabular} & $\begin{array}{l}0.5 \\
9.8\end{array}$ & $\begin{array}{r}11.5 \\
2.0\end{array}$ & $\begin{array}{l}1.2 \\
2.0\end{array}$ & $\begin{array}{l}0.0 \\
0.3\end{array}$ & $\begin{array}{l}0.0 \\
0.8\end{array}$ & $\begin{array}{l}0.0 \\
0.0\end{array}$ & $\begin{array}{l}2.5 \\
3.9\end{array}$ & $\begin{array}{l}0.0 \\
3.7\end{array}$ & $\begin{array}{l}0.5 \\
3.1\end{array}$ & $\begin{array}{l}0.1 \\
0.1\end{array}$ \\
\hline 72 & $\begin{array}{l}\text { 富山地方 } \\
\text { 鉄道 }\end{array}$ & 61 & \begin{tabular}{|l|} 
発 \\
着
\end{tabular} & $\begin{array}{r}5.6 \\
12.3\end{array}$ & $\begin{array}{l}0.2 \\
2.9\end{array}$ & $\begin{array}{l}8.0 \\
1.5\end{array}$ & $\begin{array}{l}0.0 \\
0.4\end{array}$ & $\begin{array}{l}0.1 \\
0.1\end{array}$ & $\begin{array}{l}0.1 \\
1.7\end{array}$ & $\begin{array}{l}1.5 \\
3.4\end{array}$ & $\begin{array}{l}0.1 \\
2.8\end{array}$ & $\begin{array}{l}1.2 \\
9.5\end{array}$ & $\begin{array}{l}0.5 \\
1.3\end{array}$ \\
\hline 73 & 加越能鉄道 & 62 & \begin{tabular}{|l|} 
発 \\
着
\end{tabular} & $\begin{array}{l}0.1 \\
2.8\end{array}$ & $\begin{array}{r}8.2 \\
37.0\end{array}$ & $\begin{array}{l}8.2 \\
2.6\end{array}$ & $\overline{0.7}$ & 0.1 & - & $\begin{array}{l}0.0 \\
4.3\end{array}$ & $\begin{array}{l}0.2 \\
0.4\end{array}$ & $\begin{array}{l}0.4 \\
6.6\end{array}$ & $\begin{array}{l}0.2 \\
0.3\end{array}$ \\
\hline 74 & $\begin{array}{l}\text { 北陸鉄道 } \\
\text { (加南線) }\end{array}$ & 5 & \begin{tabular}{|l|} 
発 \\
着
\end{tabular} & $\begin{array}{r}0.8 \\
24.3\end{array}$ & $\begin{array}{l}3.0 \\
7.9\end{array}$ & $\overline{0.1}$ & - & - & - & $3 \overline{5}$ & $\overline{0.7}$ & $\overline{9.2}$ & $\overline{1.1}$ \\
\hline 75 & (北陸鉄道 & 138 & \begin{tabular}{|l|} 
発 \\
着
\end{tabular} & $\begin{array}{r}4.8 \\
12.8\end{array}$ & $\begin{array}{l}1.7 \\
5.6\end{array}$ & $\begin{array}{l}1.4 \\
2.3\end{array}$ & $\begin{array}{l}1.9 \\
1.5\end{array}$ & $\begin{array}{l}0.1 \\
0.0\end{array}$ & $\begin{array}{l}0.9 \\
0.6\end{array}$ & $\begin{array}{l}0.3 \\
2.2\end{array}$ & $\begin{array}{l}0.3 \\
1.6\end{array}$ & $\begin{array}{r}0.7 \\
15.0\end{array}$ & $\begin{array}{l}2.0 \\
0.6\end{array}$ \\
\hline 76 & $\begin{array}{l}\text { 北陸鉄道 } \\
\text { (溅野川線) }\end{array}$ & 15 & \begin{tabular}{|l|} 
発 \\
着
\end{tabular} & $\begin{array}{r}0.9 \\
19.7\end{array}$ & $\begin{array}{r}0.4 \\
18.7\end{array}$ & $\begin{array}{l}0.1 \\
0.9\end{array}$ & $\begin{array}{l}1.4 \\
0.0\end{array}$ & - & $\overline{0.0}$ & $\begin{array}{l}0.4 \\
2.1\end{array}$ & $\begin{array}{l}0.5 \\
9.7\end{array}$ & $\begin{array}{l}0.1 \\
1.2\end{array}$ & $\begin{array}{l}0.4 \\
0.2\end{array}$ \\
\hline 77 & $\begin{array}{l}\text { 北陸鉄道 } \\
\text { (能登線) }\end{array}$ & 57 & \begin{tabular}{|l|} 
発 \\
着
\end{tabular} & $\begin{array}{r}6.6 \\
15.5\end{array}$ & $\begin{array}{l}7.0 \\
1.5\end{array}$ & $\begin{array}{r}11.7 \\
2.0\end{array}$ & $\overline{0.4}$ & $\begin{array}{l}0.7 \\
0.2\end{array}$ & $\overline{1.0}$ & $\begin{array}{r}0.6 \\
16.4\end{array}$ & $\begin{array}{l}0.0 \\
2.4\end{array}$ & $\begin{array}{l}1.7 \\
6.0\end{array}$ & $\begin{array}{l}0.1 \\
0.3\end{array}$ \\
\hline 78 & \begin{tabular}{|c|} 
京福電気鉄道 \\
(福井支社)
\end{tabular} & 210 & $\begin{array}{l}\text { 発 } \\
\text { 着 }\end{array}$ & $\begin{array}{l}3.6 \\
6.5\end{array}$ & $\begin{array}{r}10.4 \\
3.5\end{array}$ & $\begin{array}{r}11.3 \\
0.9\end{array}$ & $\begin{array}{l}0.4 \\
0.4\end{array}$ & $\begin{array}{l}0.2 \\
0.6\end{array}$ & $\begin{array}{l}0.8 \\
0.5\end{array}$ & $\begin{array}{l}0.1 \\
7.5\end{array}$ & $\begin{array}{l}0.1 \\
7.8\end{array}$ & $\begin{array}{r}0.3 \\
15.2\end{array}$ & $\begin{array}{l}0.3 \\
0.7\end{array}$ \\
\hline 79 & 福井鉄道 & 78 & $\begin{array}{l}\text { 発 } \\
\text { 着 }\end{array}$ & $\begin{array}{r}0.2 \\
12.0\end{array}$ & $\begin{array}{l}1.8 \\
3.5\end{array}$ & $\begin{array}{l}6.0 \\
0.3\end{array}$ & $\begin{array}{l}1.0 \\
0.3\end{array}$ & $\begin{array}{l}0.0 \\
0.0\end{array}$ & - & $\begin{array}{l}0.7 \\
7.2\end{array}$ & $\begin{array}{l}0.0 \\
5.8\end{array}$ & $\begin{array}{l}2.9 \\
6.9\end{array}$ & $\begin{array}{l}0.1 \\
0.2\end{array}$ \\
\hline 80 & 江若鉄道 & 89 & $\begin{array}{l}\text { 発 } \\
\text { 着 }\end{array}$ & $\begin{array}{l}0.1 \\
2.8\end{array}$ & $\begin{array}{l}5.3 \\
0.2\end{array}$ & $\begin{array}{r}14.8 \\
4.2\end{array}$ & $\begin{array}{l}0.2 \\
1.0\end{array}$ & $\overline{0.0}$ & - & $\overline{7.3}$ & $\overline{0 .}$ & $\begin{array}{l}0.2 \\
3.3\end{array}$ & $\begin{array}{l}0.1 \\
0.1\end{array}$ \\
\hline 81 & 別府鉄道 & 225 & \begin{tabular}{|l} 
発 \\
着
\end{tabular} & $\begin{array}{r}0.2 \\
15.8\end{array}$ & $\overline{0.4}$ & - & $\overline{0.3}$ & - & $\underline{0.0}$ & $\begin{array}{r}76.2 \\
1.3\end{array}$ & $\underline{0.0}$ & $\overline{0.1}$ & $\begin{array}{l}0.0 \\
0.2\end{array}$ \\
\hline 82 & $\begin{array}{l}\text { 南海 } \\
\text { 電気鉄道 }\end{array}$ & 469 & $\begin{array}{l}\text { 発 } \\
\text { 着 }\end{array}$ & $\begin{array}{r}13.9 \\
6.5\end{array}$ & $\begin{array}{l}3.1 \\
9.8\end{array}$ & $\begin{array}{l}3.8 \\
8.1\end{array}$ & $\begin{array}{l}0.4 \\
0.2\end{array}$ & $\begin{array}{l}0.2 \\
1.1\end{array}$ & $\begin{array}{l}0.1 \\
0.1\end{array}$ & $\begin{array}{l}0.6 \\
0.7\end{array}$ & $\begin{array}{l}0.8 \\
0.9\end{array}$ & $\begin{array}{l}1.0 \\
6.5\end{array}$ & $\begin{array}{l}1.4 \\
0.8\end{array}$ \\
\hline 83 & $\begin{array}{l}\text { 和歌山電気軌 } \\
\text { 道 (鉄道線) }\end{array}$ & 12 & \begin{tabular}{|l} 
発 \\
着
\end{tabular} & $\begin{array}{l}0.6 \\
0.7\end{array}$ & $\underline{0.2}$ & $\begin{array}{l}7.8 \\
4.0\end{array}$ & $\begin{array}{l}0.2 \\
7.1\end{array}$ & $\overline{1.6}$ & - & $\begin{array}{r}0.9 \\
32.8\end{array}$ & $\overline{0 . \overline{4}}$ & $\begin{array}{r}0.4 \\
23.8\end{array}$ & $\begin{array}{l}0.7 \\
0.6\end{array}$ \\
\hline 84 & $\begin{array}{l}\text { 野上 } \\
\text { 電気鉄道 }\end{array}$ & 12 & 発 & - & $\begin{array}{l}1.7 \\
0.5\end{array}$ & $23 . \overline{5}$ & $\overline{2.1}$ & $\begin{array}{r}20.0 \\
6.9\end{array}$ & - & $19 \overline{1}$ & $\overline{1.2}$ & $\overline{2.8}$ & $\overline{0.2}$ \\
\hline 85 & 有田鉄道 & 54 & $\begin{array}{l}\text { 登 } \\
\text { 着 }\end{array}$ & $\begin{array}{l}0.3 \\
0.6\end{array}$ & $\begin{array}{r}23.7 \\
0.2\end{array}$ & $\begin{array}{r}23.4 \\
5.0\end{array}$ & $\overline{0.1}$ & $\begin{array}{l}0.0 \\
0.7\end{array}$ & - & $\begin{array}{r}0.2 \\
12.1\end{array}$ & $\overline{0.1}$ & $28 \overline{5}$ & $\begin{array}{l}0.8 \\
0.1\end{array}$ \\
\hline 86 & $\begin{array}{l}\text { 御坊 } \\
\text { 臨港鉄道 }\end{array}$ & 61. & 発 & $\begin{array}{l}0.2 \\
0.6\end{array}$ & $\begin{array}{r}44.3 \\
0.0\end{array}$ & $\begin{array}{l}2.8 \\
0.6\end{array}$ & $\begin{array}{l}0.1 \\
0.1\end{array}$ & 0.0 & - & $\overline{0.5}$ & - & $\begin{array}{r}1.4 \\
10.4\end{array}$ & $\begin{array}{l}0.7 \\
0.7\end{array}$ \\
\hline 87 & $\begin{array}{l}\text { 三重交通 } \\
\text { (志摩線) }\end{array}$ & 58 & $\begin{array}{l}\text { 発 } \\
\text { 着 }\end{array}$ & $\begin{array}{l}2.9 \\
1.0\end{array}$ & $\begin{array}{l}0.4 \\
0.8\end{array}$ & $\begin{array}{r}10.4 \\
8.4\end{array}$ & $\overline{0.4}$ & $\begin{array}{l}0.3 \\
0.1\end{array}$ & 0.0 & $\begin{array}{r}0.2 \\
14.4\end{array}$ & $\overline{0.2}$ & $\begin{array}{r}0.0 \\
21.2\end{array}$ & $\begin{array}{l}0.1 \\
0.1\end{array}$ \\
\hline 88 & 北丹鉄道 & 33 & $\begin{array}{l}\text { 発 } \\
\text { 着 }\end{array}$ & 4.8 & $\begin{array}{r}44.6 \\
0.8\end{array}$ & $\underline{0.8}$ & $\overline{0.5}$ & - & $\overline{-}$ & $\overrightarrow{3.4}$ & $\overline{6.0}$ & $\overline{3.5}$ & $\overline{0.1}$ \\
\hline 89 & 加悦鉄道 & 30 & $\begin{array}{l}\text { 登 } \\
\text { 着 }\end{array}$ & $\begin{array}{r}12.4 \\
4.0\end{array}$ & $\begin{array}{r}32.7 \\
6.0\end{array}$ & $\overline{0 . \overline{2}}$ & - & - & - & $\overline{7.7}$ & $\overline{1.4}$ & $\begin{array}{l}0.4 \\
9.7\end{array}$ & $\begin{array}{l}0.8 \\
0.5\end{array}$ \\
\hline 90 & $\mid \begin{array}{l}\text { 是年自動車 } \\
\text { (法勝寺電鉄) }\end{array}$ & 9 & $\begin{array}{l}\text { 発 } \\
\text { 着 }\end{array}$ & $\overline{1.2}$ & $\begin{array}{r}30.7 \\
0.5\end{array}$ & $\begin{array}{r}28.0 \\
0.6\end{array}$ & $\overline{1.7}$ & 二 & 二 & $21 . \overline{6}$ & - & $6 . \overline{0}$ & 1.0 \\
\hline 91 & $\begin{array}{c}\text { 一畑電気鉄道 } \\
\text { (広瀬線) }\end{array}$ & 35 & 発 & $\overline{0 . \overline{2}}$ & $\begin{array}{r}78.5 \\
0.2\end{array}$ & 1.6 & - & - & - & $\begin{array}{l}0.2 \\
3.8\end{array}$ & $\overline{0.8}$ & $\overline{6.4}$ & $\overline{0.1}$ \\
\hline 92 & $\mid$\begin{tabular}{|} 
一畑電気鉄道 \\
$\left(\begin{array}{l}\text { 北松江線 } \\
\text { 立久蚛線 }\end{array}\right)$
\end{tabular} & 56 & \begin{tabular}{|l} 
発 \\
着
\end{tabular} & $\begin{array}{l}2.2 \\
2.7\end{array}$ & $\begin{array}{r}29.0 \\
0.1\end{array}$ & $\begin{array}{l}6.2 \\
0.2\end{array}$ & $\overline{1.0}$ & $\begin{array}{l}0.1 \\
0.0\end{array}$ & 0.1 & $\begin{array}{l}0.1 \\
2.9\end{array}$ & $0 . \overline{2}$ & $\begin{array}{l}0.3 \\
5.3\end{array}$ & $\begin{array}{l}0.2 \\
0.2\end{array}$ \\
\hline
\end{tabular}




\begin{tabular}{|c|c|c|c|c|c|c|c|c|c|c|c|c|c|}
\hline \multirow{2}{*}{ 農産加工品 } & \multirow{2}{*}{$\begin{array}{c}\text { 綫維関係品 } \\
\%\end{array}$} & \multirow{2}{*}{$\begin{array}{l}\text { パルプ・ } \\
\text { 紙類 \% }\end{array}$} & \multirow{2}{*}{ 䕓工品\% } & \multirow{2}{*}{ その他\% } & \multirow{2}{*}{ 合計比率 \% } & \multirow{2}{*}{ 合計卜ン数 } & \multirow{2}{*}{$\begin{array}{c}\text { 発着総計 } \\
\text { トン数 }\end{array}$} & \multirow{2}{*}{$\left|\begin{array}{c}10 \% \text { 以を } \\
\text { 占める品目名 }\end{array}\right|$} & \multicolumn{4}{|c|}{ 各品目群の比率 } & \multirow{2}{*}{ 分類 } \\
\hline & & & & & & & & & 1 & $\square$ & 八। & 計 & \\
\hline $\begin{array}{l}0.2 \\
2.4\end{array}$ & $\begin{array}{l}0.9 \\
3.3\end{array}$ & $\begin{array}{l}0.0 \\
1.3\end{array}$ & $\overline{0.1}$ & $\begin{array}{r}10.4 \\
6.6\end{array}$ & $\begin{array}{l}22.3 \\
77.7\end{array}$ & $\begin{array}{r}44,557 \\
155,066\end{array}$ & 199,623 & 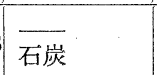 & $\begin{array}{c}\% \\
15\end{array}$ & $\begin{array}{c}\% \\
46\end{array}$ & $\begin{array}{r}\% \\
40\end{array}$ & $\begin{array}{r}\% \\
100\end{array}$ & III \\
\hline $\begin{array}{l}0.0 \\
0.1\end{array}$ & $\begin{array}{l}0.5 \\
2.5\end{array}$ & $\underline{0.1}$ & $\begin{array}{l}0.0 \\
0.5\end{array}$ & $\begin{array}{r}8.4 \\
10.8\end{array}$ & $\begin{array}{l}42.5 \\
57.5\end{array}$ & $\begin{array}{l}151,878 \\
205,169\end{array}$ & 357,047 & $\begin{array}{l}\text { セメント } \\
\text { 石灰石 }\end{array}$ & 13 & 59 & 28 & 100 & III \\
\hline- & - & - & $\overline{0.0}$ & $\begin{array}{l}4.4 \\
1.2\end{array}$ & $\begin{array}{r}91.9 \\
8.1\end{array}$ & $\begin{array}{r}33,237 \\
2,931\end{array}$ & 36,168 & $\begin{array}{l}\text { 砂利捄よび砂原 } \\
\text { 製材 }\end{array}$ & 42 & 47 & 10 & 100 & $\mathrm{IIb}$ \\
\hline $\begin{array}{l}0.3 \\
0.2\end{array}$ & $\begin{array}{l}0.5 \\
0.8\end{array}$ & $\begin{array}{l}1.1 \\
0.8\end{array}$ & $\begin{array}{l}0.0 \\
0.3\end{array}$ & $\begin{array}{l}20.0 \\
18.6\end{array}$ & $\begin{array}{l}48.5 \\
51.5\end{array}$ & $\begin{array}{l}1,522,125 \\
1,619,295\end{array}$ & $3,141,420$ & - & 7 & 41 & 53 & 100 & III \\
\hline 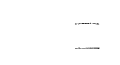 & - & $\begin{array}{l}7.8 \\
4.4\end{array}$ & $\overline{0.2}$ & $\begin{array}{l}10.6 \\
24.3\end{array}$ & $\begin{array}{l}55.4 \\
44.6\end{array}$ & $\begin{array}{l}29,192 \\
23,484\end{array}$ & 52,676 & 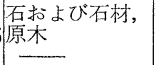 & 21 & 33 & 47 & 100 & IIc \\
\hline- & $\underline{0.3}$ & - & $\begin{array}{l}0.0 \\
1.3\end{array}$ & $\begin{array}{l}2.1 \\
1.1\end{array}$ & $\begin{array}{l}77.1 \\
22.9\end{array}$ & $\begin{array}{r}307,944 \\
91,098\end{array}$ & 399,042 & 石灰石, 石灰 & 0 & 95 & 5 & 100 & III \\
\hline$\overline{0.1}$ & $\overline{0.0}$ & - & $\overline{0.9}$ & $\begin{array}{l}29.4 \\
19.3\end{array}$ & $\begin{array}{l}51.5 \\
48.5\end{array}$ & $\begin{array}{l}99,477 \\
93,546\end{array}$ & 193,023 & $\begin{array}{l}\text { 陶磁器, 煉瓦打 } \\
\text { よび瓦 } \\
\text { 石炭 }\end{array}$ & 1 & 42 & 58 & 100 & III \\
\hline$\overline{0.0}$ & $\overline{0.0}$ & - & - & $\begin{array}{l}3.6 \\
3.9\end{array}$ & $\begin{array}{l}75.2 \\
24.8\end{array}$ & $\begin{array}{l}489,543 \\
161,876\end{array}$ & 651,419 & $\begin{array}{l}\text { セxント } \\
\text { 石炭 }\end{array}$ & 2 & 90 & 8 & 100 & III \\
\hline $\begin{array}{l}0.6 \\
1.0\end{array}$ & $\begin{array}{l}0.0 \\
0.2\end{array}$ & 12.1 & $\underline{0.2}$ & $\begin{array}{l}2.7 \\
4.7\end{array}$ & $\begin{array}{l}67.1 \\
32.9\end{array}$ & $\begin{array}{l}92,581 \\
45,407\end{array}$ & 137,988 & 砂利および砂, 米 & 38 & 44 & 18 & 100 & IIb \\
\hline $\begin{array}{l}0.7 \\
0.4\end{array}$ & $\begin{array}{l}0.4 \\
0.3\end{array}$ & $\begin{array}{l}0.0 \\
1.6\end{array}$ & $\begin{array}{l}0.0 \\
0.1\end{array}$ & $\begin{array}{l}27.7 \\
26.8\end{array}$ & $\begin{array}{l}45.1 \\
54.9\end{array}$ & $\begin{array}{l}457,134 \\
555,604\end{array}$ & $1,012,738$ & & 17 & 18 & 65 & 100 & IV \\
\hline $\begin{array}{l}0.4 \\
1.8\end{array}$ & $\begin{array}{l}4.0 \\
3.6\end{array}$ & $\begin{array}{l}5.6 \\
1.4\end{array}$ & $\begin{array}{l}0.9 \\
0.0\end{array}$ & $\begin{array}{r}6.6 \\
22.5\end{array}$ & $\begin{array}{l}34.8 \\
65.2\end{array}$ & $\begin{array}{l}123,399 \\
230,978\end{array}$ & 354,377 & & 12 & 34 & 54 & 100 & III \\
\hline$\overline{0.2}$ & $\begin{array}{l}9.0 \\
8.1\end{array}$ & $\overline{0.0}$ & $\begin{array}{l}0.1 \\
0.1\end{array}$ & $\begin{array}{l}5.5 \\
4.8\end{array}$ & $\begin{array}{l}32.0 \\
68.0\end{array}$ & $\begin{array}{l}17,931 \\
38,204\end{array}$ & 56,135 & $\overline{\text { 原木 }}$ & 21 & 13 & 66 & 100 & IV \\
\hline$\overline{0.2}$ & $\overline{0.1}$ & $\overline{0.4}$ & - & $\begin{array}{l}23.6 \\
25.0\end{array}$ & $\begin{array}{l}27.4 \\
72.6\end{array}$ & $\begin{array}{l}2,206 \\
5,846\end{array}$ & 8,052 & $\overline{\text { 鋼材 }}$ & 7 & 26 & 68 & 100 & IV \\
\hline $\begin{array}{l}0.0 \\
0.4\end{array}$ & $\begin{array}{l}0.2 \\
0.1\end{array}$ & $\begin{array}{l}0.4 \\
0.0\end{array}$ & $\underline{0.4}$ & $\begin{array}{l}23.6 \\
18.7\end{array}$ & $\begin{array}{l}38.7 \\
61.3\end{array}$ & $\begin{array}{r}92,166 \\
146,005\end{array}$ & 238,171 & セメント & 8 & 23 & 69 & 100 & IV \\
\hline $\begin{array}{l}1.6 \\
2.9\end{array}$ & $\begin{array}{l}0.2 \\
0.2\end{array}$ & $\begin{array}{l}0.9 \\
6.2\end{array}$ & $\underline{0.3}$ & $\begin{array}{l}17.3 \\
13.9\end{array}$ & $\begin{array}{l}24.4 \\
75.6\end{array}$ & $\begin{array}{l}23,833 \\
73,967\end{array}$ & 97,800 & 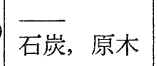 & 4 & 34 & 62 & 100 & III \\
\hline $\begin{array}{l}0.3 \\
0.1\end{array}$ & $\overline{0.4}$ & - & - & $\begin{array}{r}17.3 \\
7.6\end{array}$ & $\begin{array}{l}46.0 \\
54.0\end{array}$ & $\begin{array}{l}14,322 \\
16,846\end{array}$ & 31,168 & 砂利および砂, & 36 & 27 & 37 & 100 & IIa \\
\hline $\begin{array}{l}0.2 \\
0.6\end{array}$ & $\begin{array}{l}0.1 \\
1.2\end{array}$ & $\underline{0.0}$ & $\begin{array}{l}4.3 \\
0.1\end{array}$ & $\begin{array}{r}15.2 \\
7.2\end{array}$ & $\begin{array}{l}47.4 \\
52.6\end{array}$ & $\begin{array}{l}146,622 \\
163,032\end{array}$ & 309,654 & $\begin{array}{l}\text { 米 } \\
\text { セメント }\end{array}$ & 31 & 19 & 50 & 100 & IIa \\
\hline $\begin{array}{l}0.0 \\
0.1\end{array}$ & $\begin{array}{l}5.9 \\
2.6\end{array}$ & $\begin{array}{l}0.9 \\
1.8\end{array}$ & $\begin{array}{l}5.7 \\
0.1\end{array}$ & $\begin{array}{l}13.7 \\
20.3\end{array}$ & $\begin{array}{l}39.0 \\
61.0\end{array}$ & $\begin{array}{l}51,643 \\
80,937\end{array}$ & 132,580 & $\overline{\text { 石炭 }}$ & 16 & 29 & 56 & 100 & IV \\
\hline $\begin{array}{l}0.5 \\
0.3\end{array}$ & $\overline{0.1}$ & $\overline{0.0}$ & $\begin{array}{l}0.2 \\
0.0\end{array}$ & $\begin{array}{l}19.8 \\
39.1\end{array}$ & $\begin{array}{l}41.2 \\
58.8\end{array}$ & $\begin{array}{l}34,918 \\
49,776\end{array}$ & 84,694 & 米 & 28 & 4 & 68 & 100 & IV \\
\hline- & $\overline{0.0}$ & $\begin{array}{l}0.2 \\
0.5\end{array}$ & $\overline{0.9}$ & $\begin{array}{l}2.0 \\
1.9\end{array}$ & $\begin{array}{l}78.7 \\
21.3\end{array}$ & $\begin{array}{r}120,855 \\
32,636\end{array}$ & 153,491 & 他化学肥, その料 & 1 & 92 & 6 & 100 & III \\
\hline $\begin{array}{l}2.7 \\
0.7\end{array}$ & $\begin{array}{l}0.2 \\
1.2\end{array}$ & $\begin{array}{l}0.2 \\
0.3\end{array}$ & $\begin{array}{l}0.1 \\
0.5\end{array}$ & $\begin{array}{l}14.1 \\
20.0\end{array}$ & $\begin{array}{l}42.6 \\
57.4\end{array}$ & $\begin{array}{l}426,832 \\
573,901\end{array}$ & $1,000,733$ & 硫 & 8 & 28 & 64 & 100 & IV \\
\hline$\underline{5.5}$ & - & - & $\overline{0.6}$ & $\begin{array}{l}3.6 \\
8.5\end{array}$ & $\begin{array}{l}20.0 \\
80.0\end{array}$ & $\begin{array}{r}856 \\
3,433\end{array}$ & 4,289 & $\begin{array}{l}\text { その他化学肥料 } \\
\text { セメント }\end{array}$ & 41 & 9 & 50 & 100 & I \\
\hline - & - & - & $\begin{array}{l}0.6 \\
4.5\end{array}$ & $\begin{array}{r}7.0 \\
10.0\end{array}$ & $\begin{array}{l}29.2 \\
70.8\end{array}$ & $\begin{array}{l}1,138 \\
2,751\end{array}$ & 3,889 & 类, その他化学 & 41 & 1 & 58 & 100 & I \\
\hline- & - & - & $\overline{0.2}$ & $\begin{array}{l}1.1 \\
2.8\end{array}$ & $\begin{array}{l}49.6 \\
50.4\end{array}$ & $\begin{array}{l}10,472 \\
10,647\end{array}$ & 21,119 & $\begin{array}{l}\text { 製材, 甘著 } \\
\text { セメント }\end{array}$ & 59 & 2 & 39 & 100 & I \\
\hline $\begin{array}{l}1.0 \\
0.6\end{array}$ & $\begin{array}{r}9.5 \\
16.0\end{array}$ & - & $\overline{1.2}$ & $\begin{array}{l}7.6 \\
1.7\end{array}$ & $\begin{array}{l}67.6 \\
32.4\end{array}$ & $\begin{array}{r}19,585 \\
9,378\end{array}$ & 28,963 & $\begin{array}{l}\text { 製材 } \\
\text { 綿花 }\end{array}$ & 48 & 13 & 39 & 100 & I \\
\hline$\overline{0.1}$ & - & - & $\overline{5.6}$ & $\begin{array}{r}5.9 \\
27.3\end{array}$ & $\begin{array}{l}20.3 \\
79.7\end{array}$ & $\begin{array}{r}6,219 \\
24,452\end{array}$ & 30,669 & セメント & 26 & 4 & 70 & 100 & IV \\
\hline- & - & - & - & $\begin{array}{r}34.4 \\
1.2\end{array}$ & $\begin{array}{l}79.8 \\
20.2\end{array}$ & $\begin{array}{r}15,539 \\
3,928\end{array}$ & 19,467 & 原木, 坑木 & 49 & 11 & 41 & 100 & I \\
\hline$\overline{0.7}$ & - & $\overline{1.4}$ & - & $\begin{array}{r}13.9 \\
8.3\end{array}$ & $\begin{array}{l}60.1 \\
39.9\end{array}$ & $\begin{array}{l}4,068 \\
2,697\end{array}$ & 6,765 & 銑鉄原木坑木 & 40 & 19 & 41 & 100 & I \\
\hline$\overline{1.4}$ & - & - & $\overline{0.6}$ & $\begin{array}{l}4.5 \\
2.2\end{array}$ & $\begin{array}{l}64.2 \\
35.8\end{array}$ & $\begin{array}{l}2,320 \\
1,293\end{array}$ & 3,613 & $\mid \begin{array}{l}\text { 坑木, 米 } \\
\text { その他化学肥料 }\end{array}$ & 80 & 2 & 18 & 100 & I \\
\hline- & - & - & - & $\begin{array}{l}7.3 \\
0.8\end{array}$ & $\begin{array}{l}87.7 \\
12.3\end{array}$ & $\begin{array}{r}10,700 \\
1,502\end{array}$ & 12,202 & 坑木, 製材, 木炭 & 84 & 1 & 15 & 100 & I \\
\hline$\overline{0.3}$ & $\underline{0.0}$ & $\overline{0.0}$ & $\begin{array}{l}1.2 \\
0.1\end{array}$ & $\begin{array}{r}43.1 \\
4.4\end{array}$ & $\begin{array}{l}82.4 \\
17.6\end{array}$ & $\begin{array}{l}71,654 \\
15,322\end{array}$ & 86,976 & 坑木 & 38 & 6 & 56 & 100 & I \\
\hline
\end{tabular}




\begin{tabular}{|c|c|c|c|c|c|c|c|c|c|c|c|c|c|}
\hline & 私 鉄 名 & $\begin{array}{l}\text { 稚物運 } \\
\text { 輸密度 }\end{array}$ & $\mid$ & 宏産関俰 & 林産品\% & 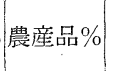 & 飼料\% & 畜産品％ & 水産品％ & 肥料\% & \begin{tabular}{|l}
$\mid$ 鉱油·油脂. \\
楽品類\%
\end{tabular} & 窯業品％ & 機械\% \\
\hline 93 & $\begin{array}{l}\text { 漛田興業 } \\
\text { 鉄直 }\end{array}$ & $\begin{array}{r}\text { トั } \\
1,744\end{array}$ & 登 & $\begin{array}{r}52.4 \\
2.1\end{array}$ & $\begin{array}{l}0.8 \\
0.4\end{array}$ & $\begin{array}{l}0.0 \\
0.1\end{array}$ & $\begin{array}{l}0.0 \\
0.0\end{array}$ & 0.0 & 二 & $0 . \overline{4}$ & $\begin{array}{l}0.2 \\
0.2\end{array}$ & $\begin{array}{r}16.3 \\
1.9\end{array}$ & $\begin{array}{l}0.1 \\
0.2\end{array}$ \\
\hline 94 & $\begin{array}{l}\text { 岡山 } \\
\text { 臨港鉄道 }\end{array}$ & 285 & 発 & $\begin{array}{r}1.3 \\
44.1\end{array}$ & $\begin{array}{l}0.2 \\
2.8\end{array}$ & $\begin{array}{l}0.0 \\
0.0\end{array}$ & $0 . \overline{0}$ & = & - & - & $\begin{array}{r}16.8 \\
0.8\end{array}$ & $\begin{array}{l}0.0 \\
0.6\end{array}$ & $\begin{array}{l}0.5 \\
0.9\end{array}$ \\
\hline 95 & $\begin{array}{l}\text { 下淺井 } \\
\text { 電鉄 }\end{array}$ & 15 & 発 & - & $\overline{0.3}$ & - & - & - & - & $\overline{0.4}$ & - & $\overline{1.8}$ & $\overline{3.2}$ \\
\hline 96 & $\begin{array}{l}\text { 倉敷市賞 } \\
\text { 鉄 }\end{array}$ & 654 & 発 & $\begin{array}{l}21.9 \\
48.7\end{array}$ & $0 . \overline{1}$ & $\begin{array}{l}3.1 \\
2.4\end{array}$ & $\overline{0 . \overline{1}}$ & - & 2.4 & $\begin{array}{l}2.7 \\
0.5\end{array}$ & $0 . \overline{1}$ & $\begin{array}{l}0.4 \\
4.4\end{array}$ & $\begin{array}{l}0.1 \\
0.4\end{array}$ \\
\hline 97 & 井笠鉄道 & 15 & 発 & $0 . \overline{2}$ & - & $\begin{array}{l}0.2 \\
1.1\end{array}$ & $=$ & $\overline{0.2}$ & $=$ & 17.7 & $\overline{3.4}$ & $\begin{array}{r}0.3 \\
20.7\end{array}$ & $1 . \overline{7}$ \\
\hline 98 & 尾道鉄道 & 0.6 & $\begin{array}{l}\text { 発 } \\
\text { 着 }\end{array}$ & - & $\overline{0.5}$ & $\overline{-}$ & - & $=$ & - & 二 & $0 . \overline{5}$ & - & $\overline{0.4}$ \\
\hline 99 & 圭佐鉄道 & 84 & 登 & $\overline{1.4}$ & $\begin{array}{r}10.4 \\
0.1\end{array}$ & $\begin{array}{r}29.4 \\
6.3\end{array}$ & $\overline{0.5}$ & $\begin{array}{l}0.1 \\
0.1\end{array}$ & $\begin{array}{l}0.0 \\
4.5\end{array}$ & $\begin{array}{r}0.0 \\
25.8\end{array}$ & $0 . \overline{2}$ & $\begin{array}{l}3.8 \\
0.8\end{array}$ & $\begin{array}{l}0.0 \\
0.3\end{array}$ \\
\hline 100 & 防石鉄道 & 37 & $\begin{array}{l}\text { 発 } \\
\text { 着 }\end{array}$ & $\overline{0 . \overline{2}}$ & $\begin{array}{r}72.0 \\
0.4\end{array}$ & 5.1 & $\overline{0.1}$ & $0 . \overline{2}$ & E- & $12 \overline{4}$ & - & $\begin{array}{l}0.1 \\
1.0\end{array}$ & $\overline{0.1}$ \\
\hline 101 & 船木鉄道 & 46 & 発 & $\begin{array}{r}96.0 \\
0.5\end{array}$ & $\begin{array}{l}0.0 \\
0.5\end{array}$ & 0.2 & $0 . \overline{0}$ & - & - & $\begin{array}{l}0.1 \\
1.9\end{array}$ & - & $\begin{array}{l}0.1 \\
0.2\end{array}$ & 0.0 \\
\hline 102 & $\begin{array}{c}\text { 門籊土地 } \\
\text { 鉄道 }\end{array}$ & 157 & 発 & $\begin{array}{l}0.0 \\
0.0\end{array}$ & 0.0 & $\begin{array}{l}28.0 \\
19.2\end{array}$ & $\begin{array}{l}5.0 \\
1.5\end{array}$ & $0 . \overline{2}$ & $=$ & $\begin{array}{r}18.4 \\
4.5\end{array}$ & $0 . \overline{1}$ & $\begin{array}{r}10.6 \\
6.8\end{array}$ & 0.1 \\
\hline 103 & $\begin{array}{l}\text { 若松市賞 } \\
\text { 鉄 }\end{array}$ & 604 & 登 & $\begin{array}{r}9.6 \\
66.8\end{array}$ & $\begin{array}{l}0.3 \\
0.1\end{array}$ & 0.4 & 0.0 & - & $\overline{-}$ & $\begin{array}{l}9.1 \\
0.0\end{array}$ & $\begin{array}{l}1.9 \\
0.0\end{array}$ & $\begin{array}{l}0.0 \\
0.4\end{array}$ & $\begin{array}{l}0.9 \\
0.2\end{array}$ \\
\hline 104 & $\begin{array}{l}\text { 踾间本鉄道 } \\
\text { 線) }\end{array}$ & 21 & $\begin{array}{l}\text { 発 } \\
\text { 着 }\end{array}$ & $\begin{array}{r}9.0 \\
62.3\end{array}$ & $\overline{1.0}$ & $\begin{array}{l}0.0 \\
5.6\end{array}$ & $=$ & $\overline{-}$ & $0 . \overline{2}$ & $0 . \overline{0}$ & $0 . \overline{0}$ & $0 . \overline{2}$ & $0 . \overline{2}$ \\
\hline 105 & 島原鉄道 & 213 & 発 & $\begin{array}{l}0.1 \\
4.9\end{array}$ & $\begin{array}{l}2.6 \\
0.7\end{array}$ & $\begin{array}{l}20.7 \\
10.1\end{array}$ & $\begin{array}{l}0.5 \\
2.9\end{array}$ & $\begin{array}{l}1.8 \\
0.1\end{array}$ & $\begin{array}{l}0.9 \\
0.1\end{array}$ & $\begin{array}{r}0.2 \\
16.7\end{array}$ & $\begin{array}{l}0.0 \\
1.9\end{array}$ & $\begin{array}{l}1.1 \\
8.5\end{array}$ & $\begin{array}{l}0.2 \\
0.5\end{array}$ \\
\hline 106 & $\begin{array}{c}\text { 大分交通 } \\
\text { (耶馬溪線) }\end{array}$ & 47 & 発 & $\begin{array}{l}14.1 \\
20.8\end{array}$ & $\begin{array}{r}28.9 \\
0.0\end{array}$ & $\begin{array}{l}3.7 \\
0.1\end{array}$ & - & $\begin{array}{l}0.2 \\
0.1\end{array}$ & - & $\begin{array}{l}0.0 \\
6.5\end{array}$ & $2 . \overline{2}$ & 3.0 & $\begin{array}{l}0.0 \\
0.8\end{array}$ \\
\hline 107 & $\begin{array}{l}\text { 大分交通 } \\
\text { (佐春線) }\end{array}$ & 46 & $\begin{array}{l}\text { 発 } \\
\text { 着 }\end{array}$ & $\begin{array}{l}0.2 \\
3.3\end{array}$ & 15.2 & $\begin{array}{r}16.6 \\
0.8\end{array}$ & $\begin{array}{l}0.0 \\
0.4\end{array}$ & 0.0 & $\begin{array}{r}16.3 \\
1.7\end{array}$ & $\begin{array}{r}0.2 \\
22.2\end{array}$ & $\begin{array}{l}0.0 \\
0.2\end{array}$ & $\begin{array}{l}0.9 \\
6.9\end{array}$ & $\begin{array}{l}0.1 \\
0.1\end{array}$ \\
\hline 108 & $\begin{array}{l}\text { 大分交通 } \\
\text { (国東線) }\end{array}$ & 71 & 登 & $\begin{array}{l}1.3 \\
0.3\end{array}$ & $\begin{array}{r}24.8 \\
0.2\end{array}$ & $\begin{array}{r}12.2 \\
0.9\end{array}$ & $0 . \overline{4}$ & $\begin{array}{l}0.1 \\
0.5\end{array}$ & 0.1 & $\begin{array}{r}0.0 \\
26.6\end{array}$ & $\overline{1.2}$ & $\begin{array}{l}0.4 \\
7.2\end{array}$ & $\begin{array}{l}0.1 \\
0.1\end{array}$ \\
\hline 109 & $\begin{array}{l}\text { 山鹿温泉 } \\
\text { 鉄 }\end{array}$ & 72 & 登 & $\begin{array}{l}0.1 \\
4.6\end{array}$ & $\begin{array}{l}4.2 \\
0.2\end{array}$ & $\begin{array}{r}36.2 \\
0.5\end{array}$ & $\begin{array}{l}0.0 \\
3.2\end{array}$ & $\begin{array}{l}0.9 \\
0.0\end{array}$ & $0 . \overline{6}$ & $\begin{array}{r}0.2 \\
31.6\end{array}$ & $\overline{1.8}$ & $\begin{array}{l}0.2 \\
7.8\end{array}$ & $\begin{array}{l}0.3 \\
0.2\end{array}$ \\
\hline 110 & 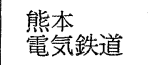 & 70 & 登 & $\begin{array}{l}0.1 \\
3.5\end{array}$ & 16.1 & $\begin{array}{l}16.6 \\
14.2\end{array}$ & $\begin{array}{l}0.0 \\
0.4\end{array}$ & $\begin{array}{l}1.1 \\
0.5\end{array}$ & $\overline{-}$ & $15 . \overline{4}$ & $0 . \overline{0}$ & $\begin{array}{l}0.4 \\
4.0\end{array}$ & $\overline{0.1}$ \\
\hline 111 & 熊延鉄道 & 111 & 発 & $\begin{array}{l}2.0 \\
7.7\end{array}$ & $\begin{array}{r}24.7 \\
0.0\end{array}$ & $\begin{array}{r}16.5 \\
0.8\end{array}$ & $\begin{array}{l}0.1 \\
0.0\end{array}$ & $\begin{array}{l}0.6 \\
0.0\end{array}$ & - & $\begin{array}{r}1.0 \\
19.5\end{array}$ & $0 . \overline{1}$ & $\begin{array}{r}17.7 \\
2.4\end{array}$ & $\begin{array}{l}0.1 \\
0.4\end{array}$ \\
\hline 112 & 南薩鉄道 & 176 & 登 & $\begin{array}{l}0.0 \\
5.6\end{array}$ & $\begin{array}{r}20.9 \\
0.3\end{array}$ & $\begin{array}{l}7.2 \\
4.1\end{array}$ & $0 . \overline{4}$ & $\begin{array}{l}4.2 \\
1.2\end{array}$ & $\begin{array}{l}1.3 \\
2.0\end{array}$ & $\begin{array}{r}0.5 \\
18.5\end{array}$ & $\overline{0.8}$ & $\begin{array}{l}0.4 \\
9.6\end{array}$ & $\begin{array}{l}0.2 \\
0.3\end{array}$ \\
\hline 113 & 宮崎交通 & 14 & 登 & $\overline{6.1}$ & $\begin{array}{l}16.4 \\
35.2\end{array}$ & $\begin{array}{r}11.8 \\
0.2\end{array}$ & $0 . \overline{4}$ & $\begin{array}{l}0.3 \\
0.4\end{array}$ & $\overline{-}$ & $\begin{array}{l}0.2 \\
6.5\end{array}$ & $\overline{-}$ & $\begin{array}{l}0.6 \\
5.5\end{array}$ & $\begin{array}{l}0.2 \\
0.3\end{array}$ \\
\hline
\end{tabular}

「各品目群の比率」欄：イ=第 1 次産業的品目群, 口=第 2 次産業的品目群, 八

本表は国鉄と貨物の連帯運輸を行なっている私鉄について, 連带発着総計トン数に対する大分類14品目のトン数百分率 実績である.

次の私鉄は資料不備のため，本表より除かれた。

花巻温泉電鉄(鉄道線)，岩手開発鉄道，仙台鉄道，福島電気鉄道(鉄道線扰よび軌道線)，日本硫黄沼尻鉄道，杤尾鉄道， 鉄道, 神戸電気鉄道, 阪神電気鉄道, 水間鉄道, 長門鉄道, 西日本鉄道 (大牟田線书上び宮地岳線), 大分交通 (豊州線), 資料：昭和 30 年度主要貨物駅別トン数年報(北海道の私鉄について) 昭和31年度主要貨物駅別トン数年報(北海道以外の私鉄について)により篗者集計.

品目群」の占める比率が非常に小さく, ひとり「そ の他の品目群」のみが大きい数值を示すというょう な場合を除いて，私鉄と沿線地域の産業との結びっ きをある程度まで表現することができると考えられ る. 第 2 表の右側の欄は，その結果を示したもので ある。

\section{III 輸送貨物の品目構成による私鉄の分類}

前章で算出された 3 品目群の構成比によって, 私 鉄の分類を試みた.すなわち, 第 1 次産業的品目群 と第 3 次産業的品目群との間の比によって分類の基 準とするもので，その基準を第 3 表のように定めた. 


\begin{tabular}{|c|c|c|c|c|c|c|c|c|c|c|c|c|c|}
\hline \multirow{2}{*}{$\begin{array}{c}\text { 農産加工品 } \\
\%\end{array}$} & \multirow{2}{*}{$\begin{array}{c}\text { 纖維関係品 } \\
\%\end{array}$} & \multirow{2}{*}{$\begin{array}{l}\text { パルプ. } \\
\text { 紙類 \% }\end{array}$} & \multirow{2}{*}{ 懵工品％ } & \multirow{2}{*}{ その他％ } & \multirow[b]{2}{*}{ 合計比率\% } & \multirow{2}{*}{ 合計トン数 } & \multirow{2}{*}{$\begin{array}{c}\text { 発着総計 } \\
\text { ト数 }\end{array}$} & \multirow{2}{*}{$\left|\begin{array}{c}10 \% \text { 以上を } \\
\text { 占める品目名 }\end{array}\right|$} & \multicolumn{4}{|c|}{ 各品目群の比率 } & \multirow{2}{*}{ 分類 } \\
\hline & & & & & & & & & 1 & 口 & 八 & 計 & \\
\hline 0.0 & - & - & $0 . \overline{0}$ & $\begin{array}{r}1.9 \\
23.2\end{array}$ & $\begin{array}{l}71.6 \\
28.4\end{array}$ & $\begin{array}{l}291,352 \\
115,612\end{array}$ & 406,964 & 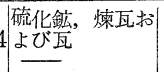 & $\begin{array}{l}\% \\
1\end{array}$ & 71 & 28 & $\begin{array}{r}\% \\
100\end{array}$ & III \\
\hline $\begin{array}{l}0.1 \\
0.0\end{array}$ & $\underline{0.5}$ & - & - & $\begin{array}{l}12.7 \\
18.6\end{array}$ & $\begin{array}{l}32.1 \\
67.9\end{array}$ & $\begin{array}{l}36,659 \\
77,685\end{array}$ & 114,344 & 4 硫酸 & 0 & 64 & 36 & 100 & III \\
\hline - & $79 . \overline{7}$ & $\overline{3.2}$ & - & $1 \overline{11.4}$ & $100 . \overline{0}$ & $2, \overline{625}$ & 2,625 & 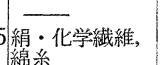 & 0 & 0 & 100 & 100 & IV \\
\hline - & - & - & $\overline{0.0}$ & $\begin{array}{l}8.8 \\
4.0\end{array}$ & $\begin{array}{l}39.4 \\
60.6\end{array}$ & $\begin{array}{r}87,238 \\
134,097\end{array}$ & 221,335 & 5 石石崖 & 6 & 74 & 20 & 100 & III \\
\hline - & $\begin{array}{r}0.2 \\
43.6\end{array}$ & $\overline{-}$ & - & $\begin{array}{l}4.9 \\
5.9\end{array}$ & $\begin{array}{r}5.6 \\
94.4\end{array}$ & $\begin{array}{r}397 \\
6,730\end{array}$ & 7,127 & $\begin{array}{l}\text { その他化学肥 } \\
\text { 料, Łxント, }\end{array}$ & 18 & 4 & 78 & 100 & IV \\
\hline - & $\begin{array}{r}0.4 \\
80.9\end{array}$ & $\overline{4.5}$ & - & $\begin{array}{r}2.5 \\
10.2\end{array}$ & $\begin{array}{r}2.9 \\
97.1\end{array}$ & $\begin{array}{r}89 \\
3,034\end{array}$ & 3,132 & 2 綃化学センイ & 0 & 0 & 100 & 100 & IV \\
\hline $\begin{array}{l}0.2 \\
4.4\end{array}$ & $0 . \overline{0}$ & $\overline{0.0}$ & $\overline{0.2}$ & $\begin{array}{l}4.3 \\
7.1\end{array}$ & $\begin{array}{l}48.3 \\
51.7\end{array}$ & $\begin{array}{l}17,127 \\
18,317\end{array}$ & 35,444 & $4 \mid \begin{array}{l}\text { 野菜 } \\
\text { その他学肥料 }\end{array}$ & 66 & 6 & 29 & 100 & I \\
\hline$\overline{0.6}$ & - & - & $\overline{0.1}$ & $\begin{array}{l}6.1 \\
1.8\end{array}$ & $\begin{array}{l}83.2 \\
16.8\end{array}$ & $\begin{array}{r}11,944 \\
2,408\end{array}$ & 14,352 & 2 & 90 & 0 & 10 & 100 & I \\
\hline - & - & - & $\overline{0.1}$ & $\begin{array}{l}0.3 \\
0.0\end{array}$ & $\begin{array}{r}96.6 \\
3.4\end{array}$ & $\begin{array}{r}36,848 \\
1,309\end{array}$ & 38,157 & 7 石炭 & 2 & 97 & 1 & 100 & III \\
\hline$\overline{0.0}$ & - & - & $1 . \overline{9}$ & $\begin{array}{l}0.7 \\
2.8\end{array}$ & $\begin{array}{l}62.7 \\
37.3\end{array}$ & $\begin{array}{l}33,834 \\
20,126\end{array}$ & 53,960 & 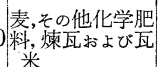 & 38 & 29 & 33 & 100 & IIa \\
\hline$\underline{0.0}$ & - & - & $\begin{array}{l}0.0 \\
0.0\end{array}$ & $\begin{array}{l}5.3 \\
5.1\end{array}$ & $\begin{array}{l}27.5 \\
72.5\end{array}$ & $\begin{array}{l}116,407 \\
307,254\end{array}$ & 423,661 & $1 \frac{}{\text { 石炭 }}$ & 1 & 88 & 11 & 100 & III \\
\hline $\begin{array}{r}10.3 \\
1.1\end{array}$ & - & $\overline{0.2}$ & $\underline{0.1}$ & $\begin{array}{l}2.9 \\
7.0\end{array}$ & $\begin{array}{l}22.4 \\
77.6\end{array}$ & $\begin{array}{l}15,042 \\
52,115\end{array}$ & 67,157 & 7 煙草 & 0 & 82 & 19 & 100 & III \\
\hline $\begin{array}{l}0.3 \\
7.4\end{array}$ & 0.0 & $\overline{0.0}$ & $\begin{array}{l}0.0 \\
0.1\end{array}$ & $\begin{array}{r}11.2 \\
6.5\end{array}$ & $\begin{array}{l}39.5 \\
60.5\end{array}$ & $\begin{array}{l}59,899 \\
91,602\end{array}$ & 151,501 & 1 甘藷 & 43 & 9 & 48 & 100 & I \\
\hline$\overline{0.1}$ & - & - & 0.1 & $\begin{array}{r}5.9 \\
13.5\end{array}$ & $\begin{array}{l}52.9 \\
47.1\end{array}$ & $\begin{array}{l}26,891 \\
23,896\end{array}$ & 50,787 & 7 鋼材, 坑木 & 39 & 37 & 24 & 100 & IIb \\
\hline$\overline{2.1}$ & 0.0 & - & $\overline{0.6}$ & $\begin{array}{l}6.8 \\
5.3\end{array}$ & $\begin{array}{l}56.4 \\
43.6\end{array}$ & $\begin{array}{l}18,968 \\
14,667\end{array}$ & 33,635 & $5 \mid \begin{array}{l}\text { 坑木, 塩 } \\
\text { その他化学肥料 }\end{array}$ & 70 & 5 & 25 & 100 & I \\
\hline $\begin{array}{l}1.0 \\
1.1\end{array}$ & - & - & $\overline{1.0}$ & $\begin{array}{r}17.2 \\
3.4\end{array}$ & $\begin{array}{l}57.2 \\
42.8\end{array}$ & $\begin{array}{l}21,092 \\
15,801\end{array}$ & 36,893 & $\begin{array}{l}\text { 坑木 } \\
\text { その他化学肥料 }\end{array}$ & 64 & 4 & 32 & 100 & I \\
\hline $2 . \overline{9}$ & - & $\overline{0.1}$ & $\begin{array}{l}0.1 \\
0.1\end{array}$ & $\begin{array}{l}2.4 \\
1.9\end{array}$ & $\begin{array}{l}44.6 \\
55.4\end{array}$ & $\begin{array}{l}13,258 \\
16,478\end{array}$ & 29,736 & 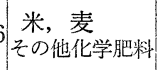 & 73 & 7 & 20 & 100 & I \\
\hline$\overline{3.7}$ & $\overline{0.4}$ & - & $\overline{0.1}$ & $\begin{array}{l}13.0 \\
10.4\end{array}$ & $\begin{array}{l}47.4 \\
52.6\end{array}$ & $\begin{array}{l}21,308 \\
23,645\end{array}$ & 44,953 & $\overline{\overline{\text { 麦 }}}$ & 49 & 4 & 47 & 100 & I \\
\hline$\overline{0.8}$ & $\underline{0.1}$ & $\overline{0.0}$ & $\overline{0.0}$ & $\begin{array}{l}2.9 \\
2.5\end{array}$ & $\begin{array}{l}65.7 \\
34.3\end{array}$ & $\begin{array}{l}36,107 \\
18,845\end{array}$ & 54,952 & $\mid \begin{array}{l}\text { 原木, 米, 石咸 } \\
\text { との他化学肥料 }\end{array}$ & 61 & 29 & 10 & 100 & I \\
\hline $\begin{array}{l}2.3 \\
2.0\end{array}$ & - & - & $\begin{array}{l}0.0 \\
0.2\end{array}$ & $\begin{array}{r}15.2 \\
2.7\end{array}$ & $\begin{array}{l}52.2 \\
47.8\end{array}$ & $\begin{array}{l}63,255 \\
57,906\end{array}$ & 121,161 & 1 製材 & 52 & 10 & 38 & 100 & I \\
\hline - & 二 & - & $\begin{array}{l}1.2 \\
0.4\end{array}$ & $\begin{array}{r}10.3 \\
4.0\end{array}$ & $\begin{array}{l}41.0 \\
59.0\end{array}$ & $\begin{array}{l}2,485 \\
3,581\end{array}$ & 6,066 & $5 \longdiv { \text { 原木 } }$ & 35 & 7 & 58 & 100 & I \\
\hline
\end{tabular}

を求めたものである．数字はすべて，1955年(昭30)度(北海道の私鉄について), 1956年(昭31)度 (北海道以外の私鉄について)

常総筑波鉄道(筑波線), 九十九里鉄道, 小湊鉄道, 東京急行電鉄, 上田丸子電鉄, 三重交通 (北勢線抢よび松阪線), 立山開発 荒尾市営鉄道.

これによる私鉄の分類は第 2 表の最右闌に示す通

りであり，またその分布を簡単に表現するため，第 1 図のごとき三角図表を作成した。この分類によっ てつくられた私鉄の類型のもつ意味について，次に 若千の考察を試みたい.

1) $I$ 型
この類型に属する線区は43線区で, 調査対象とし た私鉄の約 $38 \%$ に相当し，数的には最も多いもので ある. 農産品または林産品, あるいはその両者の発 送が多く, 更に多くの場合, 肥料の到着が大きい比 率を示すこのような線区における貨物輸送は沿線 地域の第 1 次産業と密接な関係があり, 沿線地域は 
第 3 表 私鉄分類の基準

\begin{tabular}{|c|c|c|c|c|}
\hline 分 & 類 & $\begin{array}{c}\text { 第 } 1 \text { 次产菐的 } \\
\text { 品目群の比率 } \\
\text { (A) }\end{array}$ & $\begin{array}{c}\text { 第 } 2 \text { 次産業的 } \\
\text { 品目群の比率 } \\
(\mathrm{B})\end{array}$ & $\mathrm{A} / \mathrm{B}$ \\
\hline \multicolumn{2}{|l|}{ I } & $30 \%$ 以上 & $30 \%$ 以下 & 2 以上 \\
\hline \multirow{3}{*}{ II } & $\mathrm{a}$ & $30 \%$ 以上 & $30 \%$ 以下 & \multirow{3}{*}{$\begin{array}{l}2 \text { 以下で } \\
1 / 2 \text { 以上 }\end{array}$} \\
\hline & $b$ & $30 \%$ 以上 & $30 \%$ 以上 & \\
\hline & $\mathrm{c}$ & 30\% 以下 & $30 \%$ 以上 & \\
\hline \multicolumn{2}{|l|}{ III } & $30 \%$ 以下 & $30 \%$ 以上 & 1/2 以下 \\
\hline \multicolumn{2}{|l|}{ IV } & $30 \%$ 以下 & $30 \%$ 以下 & \\
\hline
\end{tabular}

鉱工業，工業地帯，臨港地帯をもたないか，あるい はもつとしても鉄道との関連が薄いと考えられる. 一般に貨物運輸密度は低く，400トン以上の数值を 示すものは一つも存在しない. 100 トン以上の線区 は 9 本で，その他はすべて 100 トン以下の数值を示 している.

2) II 型

この類型に属する線区は17線区で, 調査詨象とし た私鉄の約 $15 \%$ に相当し，数的にはあまり多くない. 第 1 次産業的品目群と第 2 次産業的品目群の比率が 接近した数值を示すもので, 両者の相対的な関係に

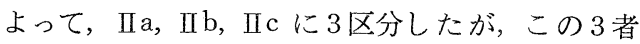
の間には質的な違いはないと考えられる．農産品と 林産品の発送，および肥料の到着が 比較的多いことはI 型に類似するが， 同時に鉱産関係品の発送または到着 も多く，その点では次のIII型と共通 する性格もみられる。このような線 区における貨物輸送は，沿線地域の 第 1 次産業および第 2 次産業の両者 と密接な関係があると考えられる.

一般に貨物運輸密度は低く, 400 卜 ン以上の数值を示すものは一つも存 在しないが，100トン以上の線区は 7 本を数える. 100 トン以下の線区 は10本であるから，両者の比率の上 では 100 トン以上の線区数の占める
比率は I 型の場合にくらべて高い. I 型と次のII型 との間の中間型と考えられる.

3） III型

この類型に属する線区は38線区で, 調查対象とし た私鉄の約 $34 \% に$ 相当し，数的にはI 型に次ぐもの である、鉱産関係品の発送および到着, セメントを 主とする䇺業品の発送が大きい比率を示す。このよ うな線区に抢ける貨物輸送は, 沿線地域の第 2 次産 業との関係が卓越している.すなわち, 特定の鉱工 業，工業地帯，臨港地帯を沿線地域にもつと考えら れる.一般に貨物運輸密度は高低両者を含むが， 400 トン以上の数值を示す線区は24本，100４00 ト ンは 8 本，100トン以下は 6 本で，全体としては， 貨物運輸密度の高い線区が多い。また逆に貨物運輸 密度の高い線区，たとえば 400 トン以上の線区をと ると，次に述べるIV型に属する 2 本を除けばその他 はすべてこのIII型に属している.

4) IV型

この類型に属する線区は15線区で，調査対象とし た私鉄の約 $13 \%$ に相当し，数的には 4 類型中最も少 ない. 第 1 次産業的品目群, 第 2 次産業的品目群と も，その比率が低く，したがって，その他の品目群

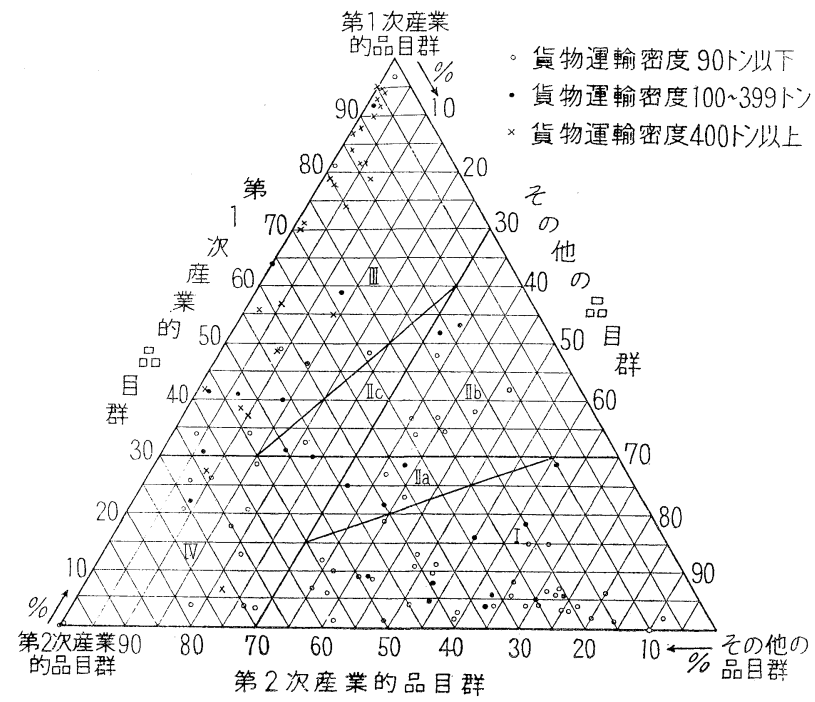

第 1 図私鉄貨物の品目群構成 
の比率が大部分を占める. その他の品目群は, 葈工 品とその他の品目を除けば，他はすべて到着品目よ り成っているからこの型は更に次のように細分でき z.

1. 特定品目到着の比率の高い線区……メント を主とする窯業品の多い大井川鉄道, 林産品の多い 加越能鉄道, 繊維関係品の多い下津井電鉄, 井笠鉄 道，尾道鉄道，水産品の多、銚子電気鉄道の計 6 線 区がこれに属する．これらの線区における貨物輸送 はそれぞれ沿線地域のダムの建設，製材工業の集積、 繊維工業の集積，水産加工業の集積と関係があると 考えられる。

2. その他の品目の発送または到着, あるいはそ の両者の比率が高い線区……主要貨物70品目および 有賃扱いの事業用品 2 品目以外の品目が多いもので, 十勝鉄道, 山形交通三山線, 近畿日本鉄道, 北陸鉄 道加南線, 北陸鉄道石川総線, 福茾鉄道, 江若鉄道, 三重交通志摩線, 南海電気鉄道の計 9 線区がこれに 属する.これらはとりあげた貨物品目が不適当で, 分類不能となった線区である.

一般にIV型に属する線区には貨物運輸密度に高低 両者が混在している. 100 トン以下が最も多くて 12 線区を占め，100４00 トンは 1 線区，400 トン以上 は 2 線区を数えるにすぎない.

IV型はこのようにその性格は多岐に亘っており， 単一の性格を包括する類型とは認めがたい、むしろ 分類の基準や資料の不備のた姓じたもので，「そ の他」または「分類不能」といいかえるべきであろ 5.

\section{IV 結語ならびに問題点}

日本の私鉄の貨物輸送密度と貨物品目構成との間 には次のような傾向がみられる。

1）1955～56年度において，国鉄と貨物の連帯運
輸を行なっていた私鉄線区 136 本中，その約 $83 \%$ に 相当する 113 線区について調查した結果では，貨物 輸送が第 1 次産業を主要な基盤とすると考えられる。 I 型 (43 線区)，第 2 次産業を主な基盤とする III 型 (38 線区)，その中間型の II 型(17 線区)，その他 (15 線区）に分類すると，I 型と而型の線区が多数を占 める.すなわち，第 1 次産業的な基盤か，第 2 次産 業的な基盤加，二者択一的に貨物輸送の上に反映し ているのが，日本の私鉄の貨物輸送の特徵の一つと いえる

2）一般に貨物運輸密度の高い線区は开型に集中 する。しかし貨物運輸密度の低い線区では I 型， II 型，II型のいずれにも例がみられる。その中では数 的にI 型が大部分を占めている.

日本において，第 1 次産業に貨物輸送の基盤を括 く私鉄 $(I$ 型)がなぜ高い貨物運輸密度をもたないの かは，日本の第 I 次産業のもつ一般的性格，とくに その流通構造や輸送単位，輸送距離，他の交通機関 との競合などに問題を解く鍵があると考えられる. ウォーレス は貨物運翰密度を高める要因の一つと して，農場密度の高いこと，遠隔の市場へ出荷する 余剩物資の存在することを挙げているが，日本では 農業は貨物運輸密度を高める決定的な要因とはなっ ておららずその効果は小さい。これは日本の農業を始 めとする第 1 次産業と交通との間の一つの特徵とい えるかもしれない。

しかし，その問題の展開のためには，各私鉄の沿 線地域における多数の具体例の分析を必要とする. これについては稿をあらためて後報するつもりであ 万.

本論文の作成に当り，御指導を賜わった青野寿郎博士な らびに東京教育大学地理学教室の諸先学に厚く御礼を申し 上げる．また快く資料の提供をして下さった日本国有鉄道 本社事務管理統計部（現コンピューター部）の各位に深く 謝意を表する次第である。(1969年 4 月 8 日受理)

7）前掲 3), Wallace, W. H, 352 374 


\section{THE CHARACTERS AND TYPES OF THE FREIGHT TRAFFIC OF JAPANESE PRIVATE RAILWAYS — A GEOGRAPHIC ANALYSIS OF THE TRAFFIC DENSITY AND THE COMPOSITION OF CARRIED GOODS}

\section{Eiichi AOKI*}

Private railways in Japan play a part of feeders to the national trunk railways, and their freight traffic is directly influenced by the economic activities of the areas along the lines. The author tried to show the situation and characters of the freight traffic of Japanese private railways through analysis of the freight traffic density (per kilometer per day), and the composition of goods carried by the private railways.

In 1955-56, there were 136 private lines dealing with freight traffic, for 113 lines of which statistical data were available. According to the data for freight traffic density, there were 12 lines over 1,000 tons, 14 over 400 tons, 25 over 100 tons, and 62 less than 100 tons.

The following five item of goods took large share in the freight traffic: agricultural products, forestry products, mining products, fertilizer, and cement and other ceramic products. The author classified the private railways into the following three types according to the composition of carried goods :

Type I : Railways serving agricultural and forestry areas $\cdots .$. Agricultural and forestry products or both of them originating from, and fertilizer terminating in these railways. 43 lines belonged to this type (38\% of the 113 lines). Their freight traffic density was small in general, none with over 1,000 tons or 400 tons, 9 lines over 100 tons, and 34 less than 100 tons.

Type III : Railways serving mining industry (coal, metal or non-metal), cement manufacturing works, heavy industrial areas, and port facilities...... Mining products originating or terminating, or cement originating. 38 lines belonged to this type ( $34 \%$ of total). Their freight traffic density was high in general, 12 lines with over 1,000 tons, 12 over 400 tons, 8 over 100 tons and 6 less than 100 tons.

Type II : Railways of an intermediate type between Type I and Type III, serving agricultural and forestry areas, and mines, manufacturing industries or ports......Agricultural, forestry and mining products originating, and fertilzer and mining products terminating. 17 lines belonged to this type ( $15 \%$ of total). Their freight traffic density was small in general, none with over 1,000 tons or 400 tons, 7 lines over 100 tons, and 10 less than 100 tons.

Fifteen railways had other characters and they were unable to be classified (13\% of total).

Significant characters of the freight traffic of Japanese private railways are that Types I and III occupied the most part of the private railways and that Type I could not show a high rank in the freight traffic density.

Geographical Review of Japan 42-6 1969. * * Tsuru City College 